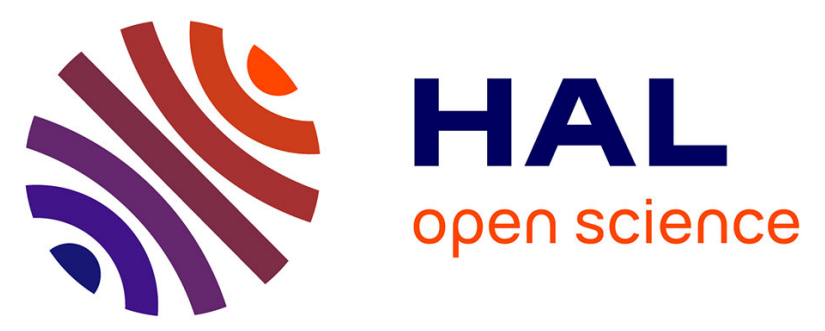

\title{
Historical and future perspectives of global soil carbon response to climate and land-use changes
}

P. Barre, Claire Chenu, Philippe Ciais, Thomas Eglin, L. Piao, Valentin

Bellassen, P. Cadule, Thomas Gasser, C. Koven, M. Reichstein, et al.

\section{- To cite this version:}

P. Barre, Claire Chenu, Philippe Ciais, Thomas Eglin, L. Piao, et al.. Historical and future perspectives of global soil carbon response to climate and land-use changes. Tellus B - Chemical and Physical Meteorology, 2010, 2010 (62B), pp.700-718. 10.1111/j.1600-0889.2010.00499.x . bioemco-00576313

\section{HAL Id: bioemco-00576313 \\ https://hal-bioemco.ccsd.cnrs.fr/bioemco-00576313}

Submitted on 30 May 2020

HAL is a multi-disciplinary open access archive for the deposit and dissemination of scientific research documents, whether they are published or not. The documents may come from teaching and research institutions in France or abroad, or from public or private research centers.
L'archive ouverte pluridisciplinaire HAL, est destinée au dépôt et à la diffusion de documents scientifiques de niveau recherche, publiés ou non, émanant des établissements d'enseignement et de recherche français ou étrangers, des laboratoires publics ou privés. 


\title{
Historical and future perspectives of global soil carbon response to climate and land-use changes
}

\author{
By T. EGLIN ${ }^{*}$, P. CIAIS ${ }^{1}$, S. L. PIAO ${ }^{2}$, P. BARRE ${ }^{3,4}$, V. BELLASSEN ${ }^{1}$, P. CADULE ${ }^{1}$, C. \\ CHENU $^{3}$, T. GASSER ${ }^{1}$, C. KOVEN ${ }^{1}$, M. REICHSTEIN ${ }^{5}$ and P. SMITH ${ }^{6},{ }^{1}$ Laboratoire des Sciences $d u$ \\ Climat et de l'Environnement, IPSL-LSCE, CEA-CNRS-UVSQ, Gif-sur-Yvette, France; ${ }^{2}$ Departement of Ecology, \\ College of Urban and Environmental Sciences, Peking University, Beijing 100871, China; ${ }^{3}$ AgroParisTEch, UMR7618 \\ Bioemco, F-78850 Thiverval-Grignon, France; ${ }^{4}$ Laboratoire de Géologie, UMR8538, Ecole normale supérieure, \\ 75005 Paris, France; ${ }^{5}$ Biogeochemical Model-Data Integration Group, Max-Planck Institute für Biogeochemistry, \\ Hans-Knoell-Strasse 10, 07745 Jena, Germany; ${ }^{6}$ Institute of Biological and Environmental Sciences, School of \\ Biological Sciences, University of Aberdeen, 23 St Machar Drive, Room G45, Aberdeen, AB24 3UU, Scotland, UK
}

(Manuscript received 7 December 2009; in final form 9 July 2010)

\begin{abstract}
In this paper, we attempt to analyse the respective influences of land-use and climate changes on the global and regional balances of soil organic carbon (SOC) stocks. Two time periods are analysed: the historical period 1901-2000 and the period 2000-2100. The historical period is analysed using a synthesis of published data as well as new global and regional model simulations, and the future is analysed using models only. Historical land cover changes have resulted globally in SOC release into the atmosphere. This human induced SOC decrease was nearly balanced by the net SOC increase due to higher $\mathrm{CO}_{2}$ and rainfall. Mechanization of agriculture after the 1950s has accelerated SOC losses in croplands, whereas development of carbon-sequestering practices over the past decades may have limited SOC loss from arable soils. In some regions (Europe, China and USA), croplands are currently estimated to be either a small C sink or a small source, but not a large source of $\mathrm{CO}_{2}$ to the atmosphere.

In the future, according to terrestrial biosphere and climate models projections, both climate and land cover changes might cause a net SOC loss, particularly in tropical regions. The timing, magnitude, and regional distribution of future SOC changes are all highly uncertain. Reducing this uncertainty requires improving future anthropogenic $\mathrm{CO}_{2}$ emissions and land-use scenarios and better understanding of biogeochemical processes that control SOC turnover, for both managed and un-managed ecosystems.
\end{abstract}

\section{Introduction}

During the past decades, research efforts have been made to improve our knowledge about the effects of climate, atmospheric $\mathrm{CO}_{2}$ and land-use change on terrestrial $\mathrm{C}$ cycle. However, the mechanisms and factors that govern global uptake and release of $\mathrm{C}$ from the terrestrial reservoir, and their regional importance, are still poorly quantified. This could only be achieved through $\mathrm{C}$ cycle modelling studies as long-term in situ measurements are very sparse and lack global coverage, and remote sensing techniques have limited capability for estimating below canopy processes such as soil respiration and are subject to significant absolute errors in carbon fluxes (Valentini et al., 2000;

\footnotetext{
*Corresponding author.

e-mail: thomas.eglin@1sce.ipsl.fr

DOI: $10.1111 /$ j.1600-0889.2010.00499.x
}

Baldocchi, 2008). There exist several C cycle modelling studies for understanding and predicting the global terrestrial carbon cycle (McGuire et al., 2001; Cao et al., 2002; Peylin et al., 2005; Zeng et al., 2005; Friedlingstein et al., 2006; Sitch et al., 2008; Piao et al., 2009a,b). However, in these studies, most models either did not incorporate land use changes, or did not separate the contributions of land use change to the global and regional $\mathrm{C}$ balances from the contributions of change in $\mathrm{CO}_{2}$, temperature and precipitation.

The goal of this study is to analyse implications of changes in climate and land use for the global and regional balance of soil organic carbon (SOC). Two contiguous time period are analysed, the historical period 1901-2000 and the future 2000-2100. Models are used for both periods, and observations for the historical period. We seek answers to the following questions:

- What was the impact of rising $\mathrm{CO}_{2}$ and changing climate on the global SOC budget during the 20th century? 
- What was the impact of land cover change and agricultural management change on SOC during the 20th century?

- Which regions have lost or gained SOC in response to land cover and climate change during the 20th century?

- How will the SOC balance change in the 21 st century in response to land cover, agricultural management and to climate change?

- What are the uncertainties?

A presentation of the SOC global distribution for large biomes is given in Section 2. The global SOC vulnerability to climate change is presented in Section 3. Historical changes in SOC induced by climate, $\mathrm{CO}_{2}$ and land cover change are analysed for different regions using a model in Section 4, and future projections in Section 5. We discuss uncertainties in Section 6.

\section{Global distribution of SOC}

The global mass of SOC is at least $\sim 2300$ PgC (Jobbágy and Jackson, 2000). It is $\sim 75 \%$ of the total land biosphere $\mathrm{C}$ reservoir given that litter and vegetation $\mathrm{C}$ stocks amount to $850 \mathrm{PgC}$ (Houghton, 2007). SOC comprises a wide range of compounds, with different age, physical and chemical properties. SOC is formed by input from litter and marginally from charcoal formation after fire (0.005-0.27 $\mathrm{PgC} \mathrm{yr}^{-1}$ according to Kuhlbusch and Crutzen, 1995). SOC is removed from the soil by microbial decomposition (heterotrophic respiration), by river export of dissolved organic carbon, by ecosystem disturbance such as fire and by wind and water erosion. Erosion acts generally on longer timescales than the former processes.
Table 1 summarizes the SOC distribution among the main biomes. The distribution of $\mathrm{C}$ in the soil compared to total ecosystem $\mathrm{C}$ stock varies greatly among biomes (from two-third to almost 100\%). SOC mass is divided between 'modern' SOC pools summing up to $2300 \mathrm{PgC}$ (Jobbágy and Jackson, 2000), and old (typically $>5000 \mathrm{yr}$ ) frozen SOC and peat SOC pools. Old SOC pools are mainly distributed in northern permafrost regions. The mass of frozen and peat SOC is huge, as recently appraised (Schuur et al., 2008; Tarnocai et al., 2009). In these regions, total SOC amounts to $\sim 1600 \mathrm{PgC}$ with $1024 \mathrm{PgC}$ in the top $3 \mathrm{~m}$ (Tarnocai et al., 2009). Old SOC pools were formed during the Pleistocene in the case of Yedoma deposits in Eastern Siberia (Zimov et al., 2006), or during the early Holocene for peat deposits in the northern high latitudes (Beilman et al., 2009). This large frozen pool is equivalent to $70 \%$ of the "conventional' C stocks. Finally, extensive peat deposits exist both in permafrost and non-permafrost regions, where decomposition is limited by temperature and/or oxygen availability in saturated organic soils. The $\mathrm{CO}_{2}$ and $\mathrm{CH}_{4}$ balance of peatlands is thus acutely sensitive to changes in both hydrology and temperature. Hence, there is a concern that these old SOC pools are vulnerable to future warming at high latitude, as will be seen in the next section.

In the other terrestrial biomes presented in Table 1, SOC stock is determined by the interaction between factors limiting decomposition and $\mathrm{C}$ inputs from plants. SOC stocks distribution between these biomes is therefore not obvious. Generally, the mean residence time of SOC, defined as the ratio of the SOC stock to heterotrophic respiration loss (Malhi et al., 2002), is longer at high latitudes for boreal forest and tundra (Bird et al., 1996;

Table 1. Soil organic carbon stocks (down to $3 \mathrm{~m}$ ) distribution among main terrestrial biomes

\begin{tabular}{|c|c|c|c|c|}
\hline Biomes & $\operatorname{Area}(\mathrm{Mha})^{\mathrm{a}}$ & SOC stocks $(\mathrm{PgC})^{\mathrm{b}}$ & Vegetation $\mathrm{C}(\mathrm{PgC})^{\mathrm{c}}$ & SOC density $\left(\mathrm{MgC} \mathrm{ha}^{-1}\right)^{\mathrm{d}}$ \\
\hline Deserts and sclerophyllous shrubs & $2650(2770-4550)$ & $332(159-191)$ & $8-10$ & $125(42)$ \\
\hline Crops & $1400(1350-1600)$ & $248(128-165)$ & $3-4$ & $177(80)$ \\
\hline Tropical savannas & $1500(2250-2760)$ & $345(247-264)$ & $66-79$ & $230(777)$ \\
\hline Temperate grasslands & $900(1250-1780)$ & $172(776-295)$ & $9-23$ & $191(236)$ \\
\hline Tundra & $800(560-927)$ & $144(775-727)$ & $2-6$ & $180(727)$ \\
\hline Tropical forests & $2450(1755)$ & $692(273-276)$ & $212-340$ & $282(723)$ \\
\hline Temperate forests & $1200(1038)$ & $262(700-753)$ & $59-139$ & $218(96)$ \\
\hline Boreal forests & $1200(1372)$ & $150(338-471)$ & $57-88$ & $91(344)$ \\
\hline Peatlands & 350 & $400-500$ & 15 & $1140-1430$ \\
\hline Permafrost $\mathrm{e}^{\mathrm{e}}$ & 1878 & 1024 & - & 545 \\
\hline
\end{tabular}

Data were gathered from Jobbagy and Jackson (2000), IPCC (2000), Davidson and Janssens (2006) and Tarnocai et al. (2009).

a Jobbagy and Jackson (2000) except for peatlands (IPCC, 2000) and permafrost (Tarnocai et al., 2009). WBGU (German Advisory Council on Global Change, 1988 in IPCC, 2000) and MRS (Mooney, Roy and Saugier, 2001 in IPCC, 2000) estimates are given in parentheses.

bJobbagy and Jackson (2000) except for peatlands (IPCC, 2000) and permafrost (Tarnocai et al., 2009). WBGU (German Advisory Council on Global Change, 1988 in IPCC, 2000) and IGBP (International Atmosphere-Biosphere Program in IPCC, 2000) estimates are given.

${ }^{\mathrm{c} C}$ Calculated from WBGU and MRS estimates (IPCC, 2000).

${ }^{\mathrm{d}}$ Calculated from Jobbagy and Jackson (2000) except for peatlands and permafrost (Tarnocai et al. 2009). WBGU estimates (IPCC, 2000) are given in parentheses.

${ }^{\text {e}}$ Permafrost partly includes peatlands, boreal forests and boreal grasslands. 
Trumbore, 2000). Primary production is the dominant process determining SOC stocks in tropical forests (Zhao et al., 2004). According to Table 1, the fraction of SOC to total ecosystem C represents roughly $60-80 \%$ in forests and more than $80 \%$ in grasslands. In tundra soils and peatland and permafrost $\mathrm{C}$ deposits, SOC represents nearly $100 \%$ of total ecosystem C stocks. It should be noted that SOC stocks estimates presented in Table 1 are generally higher than those given in the IPCC LULUCF report for the top $1 \mathrm{~m}$ of soil (IPCC, 2000) because they were estimated down to $3 \mathrm{~m}$ (Jobbagy and Jackson, 2000). This difference is particularly apparent for tropical forests (about +480 $\mathrm{PgC})$.

\section{Global vulnerability of SOC to climate and land-use changes}

\subsection{Global vulnerability of SOC to climate}

The land biospheric reservoir (soil and living biomass) constitutes a net sink of atmospheric $\mathrm{CO}_{2}$ at global scale. The size of this sink has increased alongside with increasing emissions, from $1.8 \mathrm{PgC}$ in the 1980 s to $2.6 \mathrm{PgC}$ in the $1990 \mathrm{~s}$ and $3 \mathrm{PgC}$ over 2000-2008 (Le Quéré et al., 2009). It is currently considered that land biosphere carbon sink absorbs about $30 \%$ of the anthropogenic emissions from fossil fuel combustion and deforestation every year (Canadell et al., 2007; IPCC, 2007). This sink is explained by the increased net primary productivity (NPP) driven by a variety of environmental and management factors (Nemani et al., 2003; Piao et al., 2005; Magnani et al., 2007; Ciais et al., 2008; Lewis et al., 2009). Among the environmental factors, rising $\mathrm{CO}_{2}$, warming in 'temperature-limited' ecosystems, increased rainfall in dry ecosystems, extra-nitrogen deposition in 'nitrogen-limited' ecosystems and the combination of these factors are the main causes of increased NPP (Piao et al., 2006). This increase in NPP induces higher soil C stock by increasing $\mathrm{C}$ input to soil. However, although soil contains three times more $\mathrm{C}$ than the vegetation, it is a two times smaller sink than living biomass (Reichstein, 2008). There are two reasons for that. First, in managed ecosystems, biomass is partly harvested and consequently the soil does not 'benefit' from all the increased primary productivity. Second, in some ecosystems, increased primary productivity adds $\mathrm{C}$ into biomass pools where it could be stored for decades, and the soil has therefore not 'seen' the increase in primary productivity yet. This is especially true for the woody biomass pools of forests. Yet, global increase of soil C stock is mostly due to increased foliage and fine root productivity, which are neither harvested nor long lasting biomass pools (Nemani et al., 2003; Piao et al., 2006).

However, the ability of soil to behave as a $\mathrm{C}$ sink in the future is highly uncertain because SOC decomposition is sensitive to climate and increase with temperature. Generally, soil $\mathrm{C}$ respiration rate is multiplied by roughly a factor of two for a $10^{\circ} \mathrm{C}$ warming (Raich and Schlesinger, 1992; Davidson and Janssens,
2006; Reichstein et al., 2005) if microbial activity is not limited by substrate availability or soil moisture. The potential loss of soil $\mathrm{C}$ under the future warming forecasted by climate models is six times larger than the current soil C sink (Reichstein, 2008). Large uncertainties are associated with this estimate, both in the amount and spatial distribution of warming which depends on economic development scenarios and modelled climate processes, and in the response of soil $\mathrm{C}$ to climate change.

In the future, the net balance between extra inputs and extra losses is difficult to assess. Indeed, neither SOC input nor output fluxes are linear function of climate, and these functions are uncertain. It is generally assumed that decomposition increases exponentially with temperature (Lloyd and Taylor, 1994) and productivity is a saturating function of climate. Conceptually, this means that, above a certain degree of warming, the increase of respiration will not be offset by an equivalent productivity increase, and soils will lose C. Moreover, rising atmospheric $\mathrm{CO}_{2}$ concentration and warming may no more induce productivity increase in ecosystems where nutrient availability is limited and/or where drought accompanies the warming (Angert et al., 2005). This latter response is observed in simulations of the climate-carbon coupled system. For instance, in the widely cited study of Cox et al. (2000), Amazon forest productivity drops, causing a large and uncontrolled loss of soil $\mathrm{C}$ in the future century, acting as a positive feedback to global warming. Contrary to the results of this study, most global models of the coupled climate-SOC system predict a net gain of SOC during the 21 st century even in the tropics, except for two models including the one used by Cox et al. (see Friedlingstein et al., 2006).

Moreover, in face of transient climate change, an ecosystem may lose soil $\mathrm{C}$ rapidly in response to warming while its productivity increases slowly over time. In that case, although the asymptotic value of soil $\mathrm{C}$ is theoretically proportional to the new productivity and may thus eventually increase above initial levels, a transient phase of soil $\mathrm{C}$ loss lasting several decades, followed by recovery and soil $\mathrm{C}$ build-up can be produced.

For soil layers where the $\mathrm{C}$ input are virtually zero, such as subsurface peat and permafrost $\mathrm{C}$, the process of decomposition dominates the vulnerability of soil C (Zimov et al., 2006; Khvorostyanov et al., 2008a,b). Permafrost-affected soils span a wide range of soil environments, and thus the huge 'permafrost soil carbon pool' includes carbon stocks which have built up over a variety of timescales and with differing levels of vulnerability to global warming (Fig. 1). At their surface, permafrostaffected soils have a seasonally thawing active layer, in which SOC balance is, as in temperate soils, sensitive to both litter inputs and respiration fluxes over short timescales. However, the defining feature of permafrost soils is that below the surface there exist soil layers that do not thaw, and in these layers carbon may accumulate for long periods of time, leading to the massive quantities of carbon stored there. Shallow permafrost layers often contain carbon that is transported from the active 


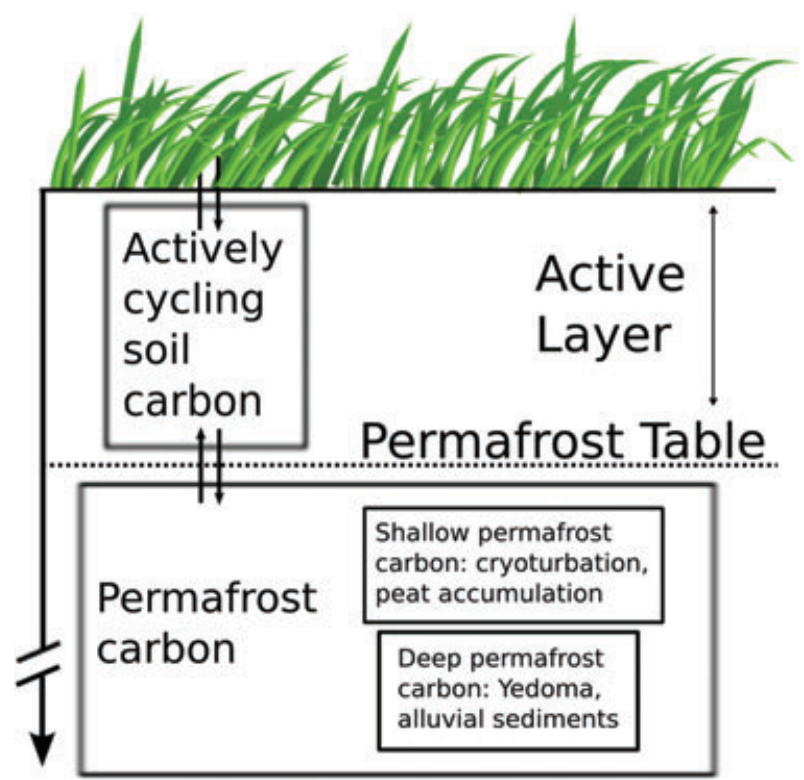

Fig. 1. Schematic of permafrost carbon cycle. Shallow permafrost carbon is likely to be the most vulnerable to deepening of active layers with warming, whereas deeper permafrost carbon may be vulnerable as well due to processes such as thermokarst or microbial heating. Roots are not figured but may intervene in both active layer and shallow permafrost.

layer through cryoturbation, and including this process in terrestrial models leads to a large increase in modelled $\mathrm{C}$ storage at high latitudes (Koven et al., 2009). The uncertainties of both the magnitude and vulnerability of these carbon pools increase with depth. Shallow permafrost carbon is clearly highly vulnerable, and field evidence suggests that carbon loss due to thawing of shallow permafrost is already taking place in Alaska (e.g. Schuur et al., 2008). The uncertainty on the quantity of carbon in deeper permafrost stocks, such as Yedoma, is much higher, as is the uncertainty on its vulnerability. Indeed, the thawing of deep permafrost within the next 100-200 years would require additional processes such as expansion of thermokarst lakes formed by meltwater (Walter et al., 2007) or release of heat by soil microorganisms (Khvorostyanov et al., 2008a,b), which are only beginning to be added to models. It is nonetheless interesting to note that most global carbon cycle models (Friedlingstein et al., 2006) show a net gain in high-latitude terrestrial carbon due to warming, while initial results using a permafrost-enabled version of ORCHIDEE (Koven C., Ringeval B., Ciais P., Friedlingstein P., personal communication) show carbon losses due to warming.

\subsection{Global vulnerability of SOC to land-use changes}

Land cover and land management also strongly impact soil C balance acting on both decomposition and input. Land use changes that began with human agriculture several millennia ago, have escalated during the last centuries. These have consisted mostly of expanding cropland and pastureland and, more recently of urbanization. Today land use change is concentrated in the tropics, where forest clearing is taking place (Houghton, 2003). Tropical forest clearing induced a direct loss of $\mathrm{C}$ in biomass of $1.4 \mathrm{PgC}$ $\mathrm{yr}^{-1}$ over 2000-2008, but clearing also causes an indirect loss of soil C (Houghton, 2003) that may last for decades after land use change (Pongratz et al., 2009). The fate of soil C in newly deforested areas converted to cropland or pastureland will depend on agricultural practice. Intensive cropping will quickly empty the former soil C pools within two to three decades (Arrouays et al., 1995; Jolivet et al., 1997; Reeves et al., 1997), whereas sustainable pasture management may stabilize them to a value close to the former tropical forest (Trumbore et al., 1995). In the following, we thus examine the effects of land use change on soil $\mathrm{C}$ pools during the last century, and into the future.

To appreciate the timescales involved in the evolution of soil $\mathrm{C}$ balance after a land use change, Fig. 2 shows the measured evolution of soil C in so-called 'bare fallow' field experiments. These soils, formerly under cropland or grassland were kept free of vegetation by human intervention during several decades, while SOC decomposition continues. Figure 2 shows that even after 40 years of bare soil conditions, the soil is continuing to lose $\mathrm{C}$, apparently without reaching a new equilibrium. The shape of SOC decay in bare fallow plots cannot be reproduced with a simple 1-pool exponential decay model. Moreover, the SOC decay differs according to the former land use (Fig. 2). For example, the Rothamsted bare fallow implemented on grassland shows an initial large $\mathrm{C}$ loss that is not observed in the Askov bare fallow implemented on arable land. This suggests that soil organic matter is composed of two or more pools, with some pools having a decay time of 50-100 years, or more. Moreover, the size of the more stable pool may depend on previous land-use (Balesdent et al., 1988).

Consequently, any change in land use or ecosystem disturbance is expected to have a long lasting effect on the soil $\mathrm{C}$ balance. Former land use will continue to exert an influence on today's soil $\mathrm{C}$ budget and pre-condition its future evolution as well. Because of the cascade of long timescales involved, one needs to take a long historical perspective to simulate land use and climate change impacts on soil $\mathrm{C}$ balance.

\subsection{Historical land cover, agricultural management and climate change effects on SOC}

To gain insights on past land-use change effects on SOC regionally, the results of a global biosphere model forced by land-use and climate changes since 1900 are analysed. This model is a process-based global ecosystem model called ORCHIDEE (ORganizing Carbon and Hydrology In Dynamic EcosystEms model; Krinner et al., 2005). ORCHIDEE was used to quantify the effects of changes in climate, atmospheric $\mathrm{CO}_{2}$ concentration and changes in land cover area on terrestrial $\mathrm{C}$ cycle for the 


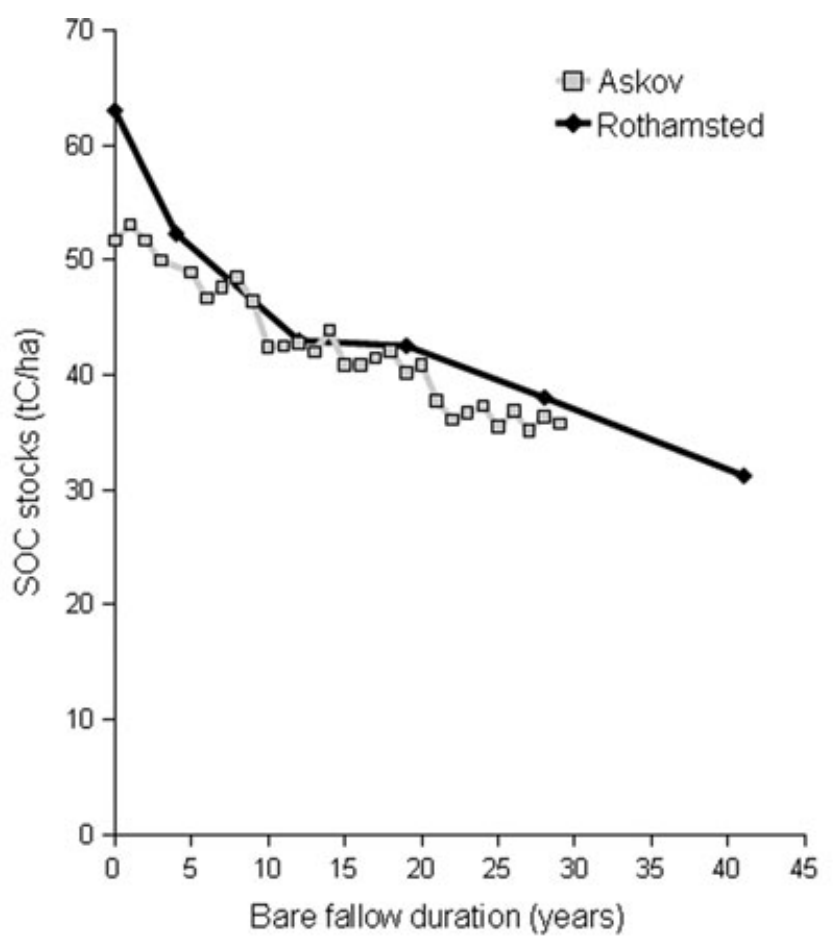

\begin{tabular}{lcccc}
\hline Site & $\begin{array}{c}\text { Historical land } \\
\text { use }\end{array}$ & $\begin{array}{c}\text { Texture }(\%) \\
\text { (Clay/Silt/Sand) }\end{array}$ & $\begin{array}{c}\text { Mean annual } \\
\text { temperature }\left({ }^{\circ} \mathrm{C}\right)\end{array}$ & $\begin{array}{c}\text { Annual rain } \\
(\mathbf{m m})\end{array}$ \\
\hline $\begin{array}{l}\text { Askov } \\
\text { (Denmark) }\end{array}$ & arable & $07 / 11 / 82$ & 7,8 & 862 \\
$\begin{array}{l}\text { Rothamsted } \\
\text { (UK) }\end{array}$ & $\begin{array}{l}\text { managed } \\
\text { grassland }\end{array}$ & $25 / 62 / 13$ & 9,5 & 712 \\
\hline
\end{tabular}

Fig. 2. Evolution of soil $\mathrm{C}$ content in bare fallow experiments in the first $23 \mathrm{~cm}$ of a silty-loam soil at Rothamsted (England) and in the first $20 \mathrm{~cm}$ of a loamy-sand soil at Askov (Denmark). Data from Askov (Askov-FL1-B4) were taken from Petersen et al. (2005). Data from Rothamsted (High field bare fallow) were redrawn from Johnston et al. (2009). period from 1901 to 2002. SOC stocks were considered to be at steady-state equilibrium in 1901 . This is a very crude assumption because human-induced land-use change has occurred before the 20th century particularly in Europe, in the Former Soviet Union and in East Asia (Pongratz et al., 2008). This human-induced land-use change is not negligible because it was estimated that about 5 millions of $\mathrm{km}^{2}$ were transformed to cropland or pasture between 800 and $1700 \mathrm{AD}$, leading SOC stocks to a significant disequilibrium in 1900 (Pongratz et al., 2009). For example, they estimated that, whereas vegetation lost about $100 \mathrm{Gt} \mathrm{C}$ from 800 to 1900 , global SOC stocks increased by about $30 \mathrm{PgC}$ due to additional plant material added to the soil pools from the converted natural vegetation. The steady-state assumption underlying the ORCHIDEE simulation results analysed below implies that the effect of land-cover change on SOC stocks is likely to be overestimated. More details about the model set up and architecture are given in Appendix.

\subsection{Historical global land cover change and SOC balance}

Both land cover and $\mathrm{CO}_{2}+$ climate changes have a strong impact in SOC balance. Running simulations taking into ac- count $\mathrm{CO}_{2}+$ climate changes only or $\mathrm{CO}_{2}+$ climate + land cover changes allow determining the relative importance of land cover change. The results of these two simulations at global scale are presented on Fig. 3a. If only $\mathrm{CO}_{2}$ and climate drivers are accounted for, NPP and thereby biomass increases (Fig. 3a). Soil C shows a slight decreasing trend until 1960, due to warming induced acceleration of SOC decomposition in Europe and in temperate North America. Elsewhere, the $\mathrm{CO}_{2}$ fertilization effect on NPP incorporated in the model increases soil $\mathrm{C}$ input in excess to warming increased decomposition. Therefore, the soil $\mathrm{C}$ balance is slightly positive over the 20th century.

By contrast, when annual land cover changes are incorporated in the study, the soil $\mathrm{C}$ stock decreases globally between 1900 and 1960. This land use induced decrease is later reversed, ending up only in a small variation of soil $\mathrm{C}, \Delta \mathrm{SOC}=-7.3$ $\mathrm{PgC}$ by year 2000. The net change represents an insignificant $0.3 \%$ decrease of the initial stocks in 1901, assumed in equilibrium. The essential point here is that land-use change has an effect on soil C change between 1901 and 2000 that is equivalent in magnitude to the effect of climate and $\mathrm{CO}_{2}$ change, but of opposite sign. These results are in agreement with the results of a modelling study by McGuire et al. (2001) who did 

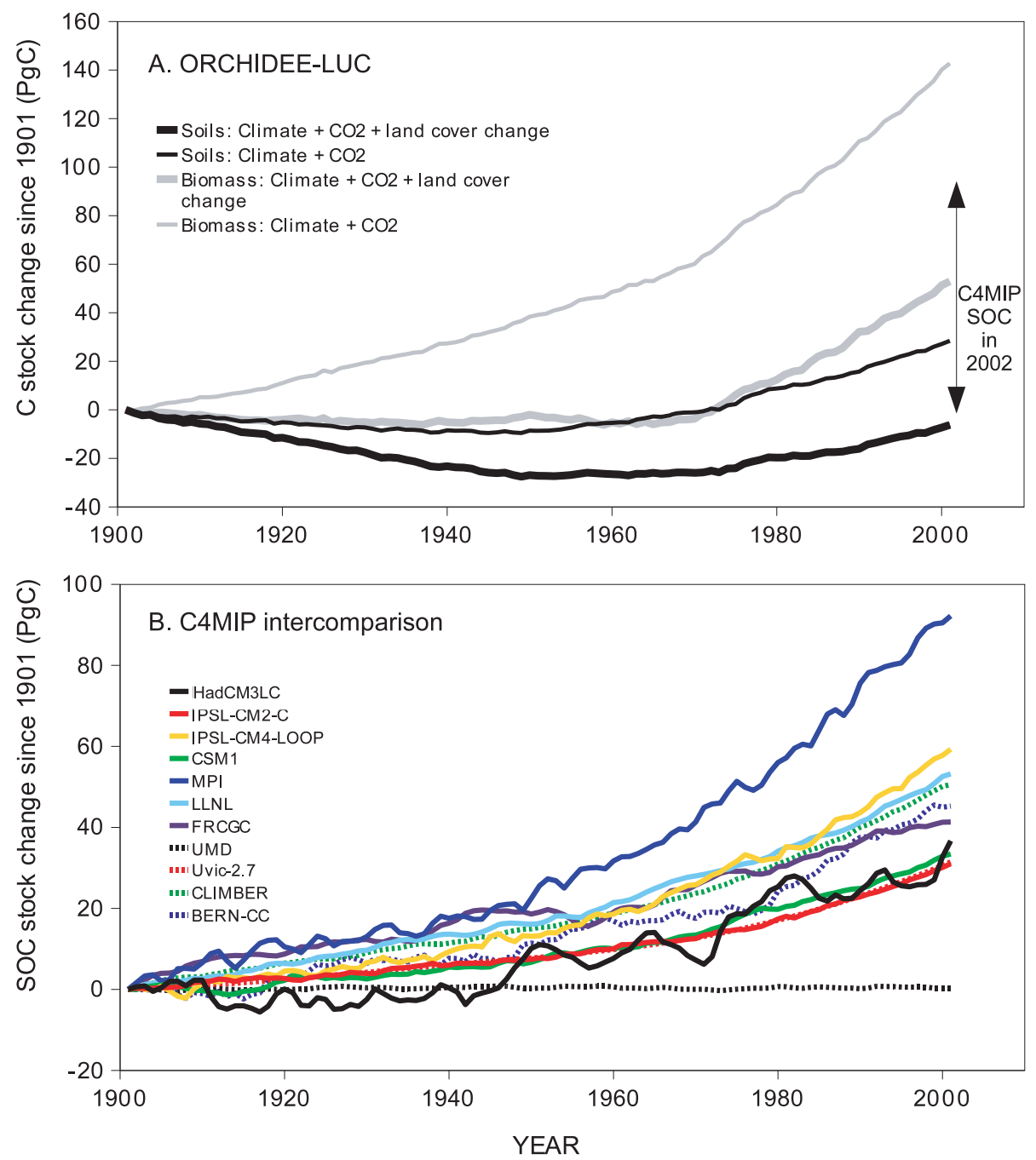

Fig. 3. Evolution (a) of global soil and vegetation $\mathrm{C}$ stocks simulated by ORCHIDEE-LUC in response to combined effects of atmospheric $\mathrm{CO}_{2}$ concentration and climate, and to combined effects of atmospheric $\mathrm{CO}_{2}$ concentration, climate and land cover change and (b) of global soil $\mathrm{C}$ stocks simulated by the eleven models of the C4MIP intercomparison (Friedlingstein et al., 2006) from 1901 to 2002.

not distinguish soil carbon pools from the total land biospheric reservoir. Hence, McGuire et al. (2001) estimate with four terrestrial biosphere models that terrestrial ecosystems transitioned during the 20th century from releasing carbon to the atmosphere ( $\sim 8.8 \mathrm{PgC}$ from 1920 to 1957 ) because of land-use changes to storing carbon ( $\sim 14.3 \mathrm{PgC}$ from 1958 to 1992$)$ mainly because of the increase in atmospheric $\mathrm{CO}_{2}$ concentration.

Because the change in NPP consecutive to forest clearing is

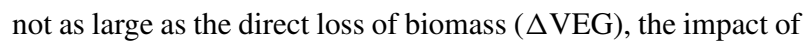
historical land cover change is more drastic on the biomass pools change than on the SOC pools change. Therefore, in our simulation, compared to the effect of $\mathrm{CO}_{2}$ and climate alone, including land cover change modifies $\triangle \mathrm{VEG}$ globally from +140 to -51 $\mathrm{PgC}$ and $\Delta \mathrm{SOC}$ only from +27 to $-7.3 \mathrm{PgC}$. This land cover effect on global SOC stocks $(-34.3 \mathrm{PgC})$ is almost half the range of global SOC changes simulated by the eleven C4MIP models for the 20th century and represents $\sim 1 / 3$ (MPI) to $\sim 100$ times (UMD) the estimated effect of climate and atmospheric $\mathrm{CO}_{2}$ changes (Figs 3a and b). Moreover, ORCHIDEE-LUC shows the only negative SOC balance. This result highlights (1) the importance of land-use change comparatively to climate change and (2) the need for consideration of past land-use change in models that were parameterized to be consistent with the current contemporary global land carbon budget. On the other hand, the model does not reproduce secondary forest ecosystem growth unless a given grid point is subject to deforestation and later to reforestation. Thus, the negative impact of deforestation on the SOC balance is probably overestimated (Shevliakova et al., 2009).

When looking at the combined effects of land use, climate and $\mathrm{CO}_{2}$ changes on the SOC balance at regional scale, we can see in Fig. 4a different behaviour between tropical regions on the 

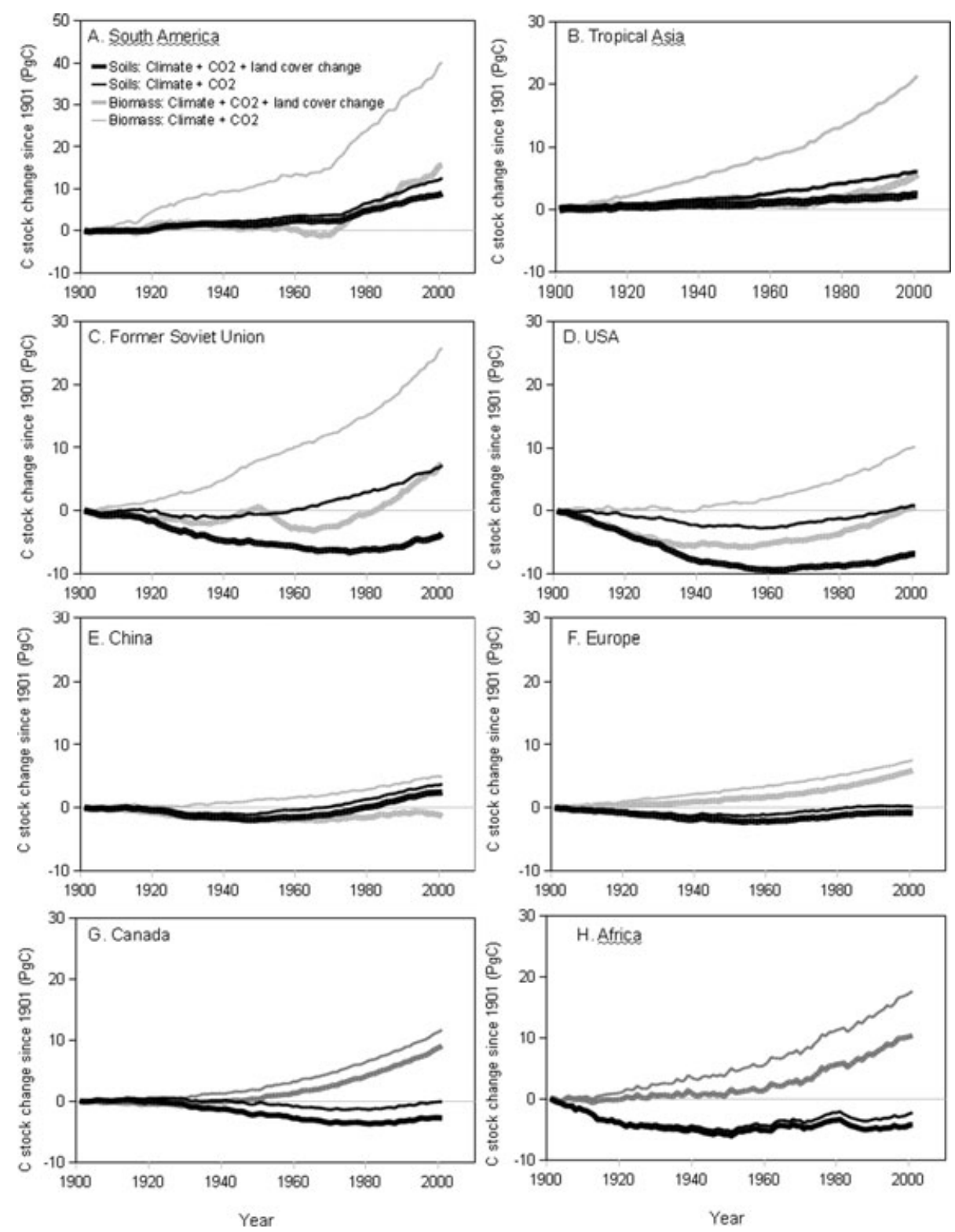

Fig. 4. Evolution of regional soil and vegetation $\mathrm{C}$ stocks simulated by ORCHIDEE-LUC in response to combined effects of atmospheric $\mathrm{CO}_{2}$ concentration and climate, and to combined effects of atmospheric $\mathrm{CO}_{2}$ concentration, climate and land cover change from 1901 to 2002.

one hand, and temperate and boreal regions on the other hand. In temperate and boreal regions, the effect of land cover change on the SOC stocks is larger than in the tropics, even though the loss of biomass is greater in the tropics.

More specifically, in the Former Soviet Union (FSU) and North America, forest clearing took place during the first half of the 20th century. This forest clearing has impacted the SOC balance with inertia, owing to the long residence times of SOC (Figs $4 \mathrm{c}$ and d). In the FSU, the modelled difference between SOC stocks with climate and $\mathrm{CO}_{2}$ changes only (S1) and SOC stocks with land-use changes (S2) is still increasing with time. In North America, this difference is rather constant after 1970, indicating that the indirect effect of land cover change on SOC stocks is stabilised. In Europe and China (Figs 4e and f), no major change in forest area took place during the 20th century (most of deforestation being earlier to that date). The SOC difference between $\mathrm{S} 2$ and $\mathrm{S} 1$ is thus negligible, indicating that land cover change did not impact SOC stocks. However, we will see below that SOC stocks in China and Europe has likely declined during the 20th Century due to intensification of agriculture. In China, large plantations created in the 1980s may contribute to an increase in SOC (Piao et al., 2009a,b), which is not well captured by the coarse scale global land cover maps used to force our model. 
In our model simulation, climate and $\mathrm{CO}_{2}$ have increased SOC stocks everywhere but in Africa (because of drought that decreased NPP, see Fig. 4h) and in Canada (because increased NPP did not compensate warming increased heterotrophic respiration, see Fig. $4 \mathrm{~g}$ ). In contrast, land cover change has diminished SOC stocks everywhere. On average, the effect of land cover change on SOC balance between 1901 and 2000 is opposite to the one of climate and $\mathrm{CO}_{2}$. Regions where land cover induced SOC losses dominate over climate and $\mathrm{CO}_{2}$-induced SOC accumulation are the USA, the FSU and Europe. These regions experienced a net loss of SOC since 1901. Oppositely, a net SOC gain since 1901 was modelled for tropical Asia, China and South America. Despite deforestation in tropical Asia and South America, the increase in NPP induced by higher $\mathrm{CO}_{2}$ and rainfall in undisturbed forests (Lewis et al., 2009) has driven the pan-tropical SOC balance positive up to the present.

\subsection{Agricultural intensity and SOC balance}

On top of climate, $\mathrm{CO}_{2}$ and land cover, land management intensity also impacts SOC stocks, especially in cultivated soils. Several studies reported that changes in the fate of cropping residues (straw and stubble), cultivation and tillage practices have a strong impact on SOC stocks (Paustian et al., 1998, 2000; West and Post, 2002). In addition, arable soil erosion (which depends on SOC content, cultivation and tillage practices) causes a significant loss of SOC in cultivated soils. However, at globalscale, accumulation of eroded soil particles in floodplains may compensate for this loss at the field scale (van Oost et al., 2007).

Changes in agriculture that took place in North America, China and Europe after 1950 have likely accelerated the SOC losses (Qiu et al., 2009). This has been illustrated by numerous site measurements (Burke et al., 1989; Paul et al., 1997), but few measurements at regional or continental scale (Mäkelä-Kurtto and Sippola, 2002; Sleutel et al., 2003; Bellamy et al., 2005).

In North America, this trend may have been reversed recently, as it has been considered that changes in agricultural practices have increased SOC sequestration during the late 30 years. Indeed, Ogle et al. (2003) estimated that adoption of reduced use of bare fallow, conservation tillage practices on cropland, and conversion of annual cropland to grass and trees in the Conservation Reserve Program (CRP) have resulted in a net gain of 10.8 $\mathrm{Tg} \mathrm{C} \mathrm{yr}^{-1}$ during the period from 1982 to 1997. Most of this gain was due to setting-aside lands in the CRP and only $1.3 \mathrm{Tg}$

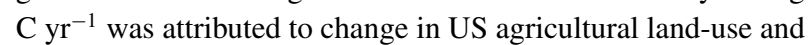
management. Using the ISAM-2 model, Jain and Yang (2005) estimated a $868 \mathrm{Tg}$ SOC increase (i.e. $43.4 \mathrm{Tg} \mathrm{C} \mathrm{yr}^{-1}$ from 1980 to 2000) in North American soils due to no-till practices. Productivity increases induced by irrigation may also have played a significant role in SOC stock increase in the USA. The SOC stock increase induced by irrigation was estimated at $21.3 \mathrm{Tg}$ $\mathrm{C}$ in the Great Plains since 1950s using the CENTURY model (Parton et al., 2005).
In China, a continuous decline in SOC levels for a wide scope of Chinese agricultural soils has been observed since the 1950s (Qiu et al., 2009). This was mainly explained by the reduction of crop residue incorporation and manure amendments, which have been the major source of SOC for most Chinese farmlands (Qiu et al., 2009). As in North America, this trend seems to have been reversed recently. New policies have been launched during the past decades to encourage farmers to return more organic matter to the soil and some agricultural fields have shown SOC sequestration (Huang and Sun, 2006; Yan et al., 2007). In addition, intensive agriculture practices, such as application of chemical fertilizer, increased irrigation in arid areas, expansion of straw incorporation, and shallow plowing have also led to an increase in the $\mathrm{C}$ sequestration of agricultural ecosystems (Huang and Sun, 2006). Preliminary estimates suggested that along with the increase of agricultural productivity and less removal of biogenic material for societal energy purposes, about $0.025-0.037 \mathrm{PgC} \mathrm{yr}^{-1}$ is potentially fixed in soil (Lal, 2004), which is slightly higher than current estimation of Huang and Sun (2006) and Xie et al. (2007). Huang and Sun (2006) analysed changes of organic carbon stocks in China's agricultural soils during the past two decades, and conclude that the mean carbon

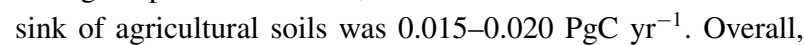
Piao et al. (2009a,b) estimated in a meta-analysis that topsoil in croplands is a net sink of $0.026 \pm 0.011 \mathrm{PgC} \mathrm{yr}^{-1}$ since the early 1980s.

In Europe, SOC change was estimated using three models including specific crop management and practice ORCHIDEE-STICS, RothC, and LPJml. In both ORCHIDEE-STICS and RothC, the simulated soil C dynamics included the effect of past changes in agricultural technology on input and tillage, as well as the effects of climate and atmospheric $\mathrm{CO}_{2}$ changes. The ORCHIDEE-STICS model was initialized with (reconstructed) ancestral farming practice and crop varieties in 1900 (Gervois et al., 2008). This model provides a net change in SOC, $\triangle \mathrm{SOC}=0.01 \pm 0.06 \mathrm{tC} \mathrm{ha}^{-1} \mathrm{yr}^{-1}$ between 1901 and 2000. This insignificant gain is mostly explained by agricultural intensification and agricultural technology changes, with a small negative contribution of recent climate change over Southern Europe (Gervois et al., 2008). Indeed, in the Iberian Peninsula and a few southern Mediterranean regions, the increase in heterotrophic respiration and a precipitation-induced reduction in soil C inputs slightly overcome positive SOC stock increment induced by agricultural technology changes. At the European scale, a strong loss of SOC is modelled when agriculture became mechanized in the 1950s. But this loss trend was reversed in the 1970s and SOC increased thereafter. Arable lands are today $\mathrm{C}$ neutral $\left(+0.16 \mathrm{tC} \mathrm{ha}^{-1} \mathrm{yr}^{-1}\right.$ with a range of $\left.0-0.3 \mathrm{tC} \mathrm{ha}^{-1} \mathrm{yr}^{-1}\right)$. This modelled small sink is not supported by regional inventories, available in UK, France, Belgium and Finland, and in some regions of Germany, which rather suggest net SOC losses (Mäkelä-Kurtto and Sippola, 2002; Sleutel et al., 2003; Bellamy et al., 2005; Smith et al., 2005a,b). However, if 
the net $\mathrm{C}$ sink provided by erosion (Lal, 2003; van Oost et al., 2007 ) is taken into account, SOC losses measured in the inventory become comparable to the model results. This confirms small net changes in the SOC balance of arable lands in Europe.

Over 1990-1999, RothC and LPJml provide Net Biome Productivities (NBP) of -7.6 and $1.3 \mathrm{~g} \mathrm{C} \mathrm{m}^{-2} \mathrm{yr}^{-1}$, respectively. It is noteworthy that these results are extremely dependent on assumptions about the management options employed and how these have changed over recent decades. In summary, the three process models integrated over Europe and the inventories available at regional-scale agree on the relatively small absolute magnitude of the net SOC balance of arable lands in Europe. However, each model's sensitivity tests point to the strong sensitivity of NBP to the assumed choice and past history of management options.

\subsection{Forest management and SOC balance}

The impact of forest management change on soil carbon has not been assessed for the past century. ORCHIDEE-FM, a novel version of ORCHIDEE includes a forest management module. Recent results emphasized the importance of forest management on SOC stocks (Bellassen et al., 2010a,b). The evolution of carbon stocks in a managed forest, as simulated by ORCHIDEE-FM, is reported on Fig. 5a. Harvesting wood increases soil carbon in the short term as $50-100 \mathrm{tC} \mathrm{ha}^{-1}$ of slash wood is added to the litter pool as coarse woody debris. This input leads to a peak in soil carbon respiration of about $+50 \%$ after harvest, which is consistent with measurements (Savage and Davidson, 2001; Pypker and Fredeen, 2002; Pregitzer and Euskirchen, 2004). During decomposition, a part of the coarse woody debris is buried in deep soil horizons, driving a smaller and slower increase in soil carbon per se (Nabuurs et al., 2008). However, in the long term the impact of forest management on SOC stock is negative: as the stems of dead trees are no longer left to feed soil carbon, the long-term litter input is lower under management than in an unmanaged forest. On average, ORCHIDEE-FM simulates a soil carbon stock reduction of about $15 \mathrm{tC} \mathrm{ha}^{-1}$ under management (Fig. 5a) compared to no management (Fig. 5b).

\section{Future changes in climate and land use, and the SOC balance}

At this stage, few integrated global model projections combine both land use change and climate change impacts on the SOC balance during the 21 st century. We discuss below results from coupled climate-carbon C4MIP models from the study of Friedlingstein et al. (2006). This study only allowed the effects of change in climate and $\mathrm{CO}_{2}$ to be examined because it did not incorporate land cover change. Hence, results from a coarse resolution terrestrial C model OSCAR (Gitz and Ciais, 2004) that incorporates both land use change and warming $\left(\sim+3.5^{\circ} \mathrm{C}\right.$ from 2000 to 2100) are analysed in counterpoint.

\subsection{Effect of climate and $\mathrm{CO}_{2}$ change}

The modelling study by Cox et al. (2000) has raised a great concern on the fact that the SOC balance is sensitive to climate via both changes in input and in decomposition. In their study, the drying of the Amazon region leads to forest dieback in the Triffid vegetation model. Forest dieback is accompanied by decreased NPP and subsequently by a large SOC loss of about $170 \mathrm{PgC}$ between 2000 and 2100. This SOC loss in tropical forests increases $\mathrm{CO}_{2}$ and climate warming by the end of the 21 st century.

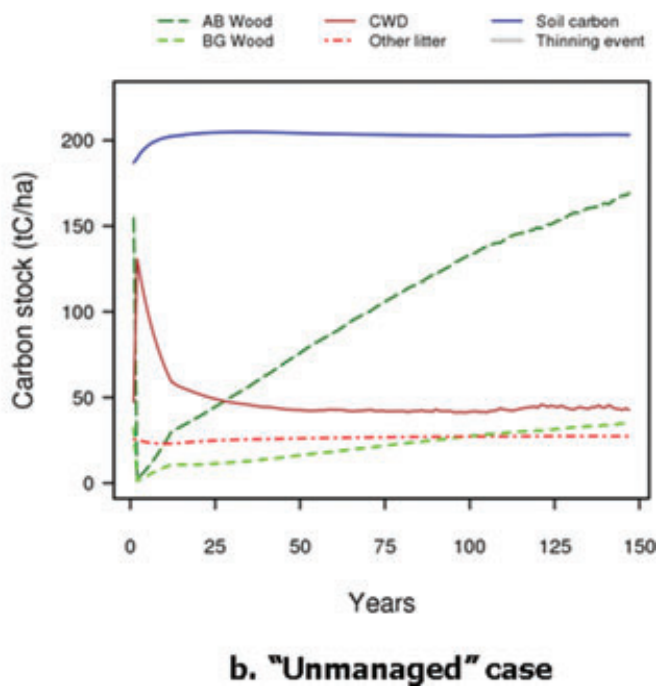

Fig. 5. Simulated carbon stocks during a rotation period in a temperate broadleaf forest stand (Bellassen et al., 2010b) (a) with management and (b) without management. AB wood is yearly average in aboveground biomass. CWD is coarse woody debris. Other litter stands for dead leaves, woody roots and fine roots. Soil carbon does not include litter. 
A more detailed study by Jones et al. (2005) using the same climate model and two different soil $\mathrm{C}$ models (RothC and Triffid) investigated the opposite role of climate through changed input and changed decomposition. The effect of temperature increase alone causes a decrease of SOC in northern regions during the 21 st century, such as Siberia and Canada. The effect of increased NPP is opposite and increased SOC. The two different $\mathrm{C}$ models show both a loss of SOC stocks but differ by $26 \mathrm{PgC}$, due to different climate sensitivity. $\mathrm{CO}_{2}$ - and climate-induced $\mathrm{C}$ input increase would drive an increase in SOC stocks everywhere by 2100, except in the Amazon region. Increase in C input and decomposition would expand the area of regions that will lose SOC to most of the tropics and mid-latitude biomes, except for high latitudes where a small SOC increase is predicted. This illustrates the need to consider future change in the SOC balance as being determined not only by the vulnerability of SOM to warming but also by increased or decreased input to the soil, including changes in litter quality (Fierer et al., 2005).

The current uncertainties on the future global SOC balance can be quantified using data from intercomparisons of many coupled climate-carbon cycle models. Uncertainties related to climate and SOC decay equations can be investigated using the results from C4MIP model intercomparison (Friedlingstein et al., 2006). Figure 6 presents the SOC changes simulated by 11 models from 2000 and 2099 at both global and regional scales. One common scenario of $\mathrm{CO}_{2}$ anthropogenic emissions (Special Report on Emission Scenarios (SRES) A2 scenario) was considered. Although the models have been parameterized to be consistent with the current contemporary global land carbon budget, their responses differ markedly. The predicted change in global SOC stocks ranges between -45.8 PgC (HadCM3LC) and $310 \mathrm{PgC}$ (MPI). In most models, soil is projected to gain $\mathrm{C}$ during the 21 st century since $\mathrm{C}$ input driven by enhanced vegetation productivity is predicted to increase more than SOC decomposition. This is true for most models even in the tropics $\left(30^{\circ} \mathrm{S}-30^{\circ} \mathrm{N}\right)$. However, for 2 of the 11 models (HadCM3LC used by Cox et al. and UMD), soils in tropical and temperate $\left(30^{\circ} \mathrm{N}-60^{\circ} \mathrm{N}\right)$ regions will lose $\mathrm{C}$ leading to global $\mathrm{C}$ release from the soil into the atmosphere. Moreover, three other models (BERN-CC, FRCGC and Uvic-2,7) show a decrease in the rate of SOC increase during the last 20 years suggesting that they would simulate SOC release during the 22 nd century if atmospheric $\mathrm{CO}_{2}$ concentration and temperature still increase. This large spread in the prediction of SOC change can be partly explained by differences in model structures (number of SOC pools ...) and parameterizations (Q10, plant respiration ...). For example, the use of a single-pool SOC model (HadCM3LC) increases the sensitivity of SOC stocks to $\mathrm{C}$ input and temperature changes (Jones et al., 2005). In this study, no consensus emerges among the models for attributing SOC sensitivity to changes in NPP or to change in respiration (Friedlingstein et al., 2006).

Large uncertainties due to natural vegetation changes and anthropogenic $\mathrm{CO}_{2}$ emissions were also evidenced by Sitch et al. (2008) using five Dynamic Global Vegetation models or DGVMs (Hyland, Triffid, LPJ, ORCHIDEE and Sheffield), four SRES scenarios of $\mathrm{CO}_{2}$ emission $(\mathrm{A} 1 \mathrm{~F} 1, \mathrm{~A} 2, \mathrm{~B} 1, \mathrm{~B} 2)$ and a
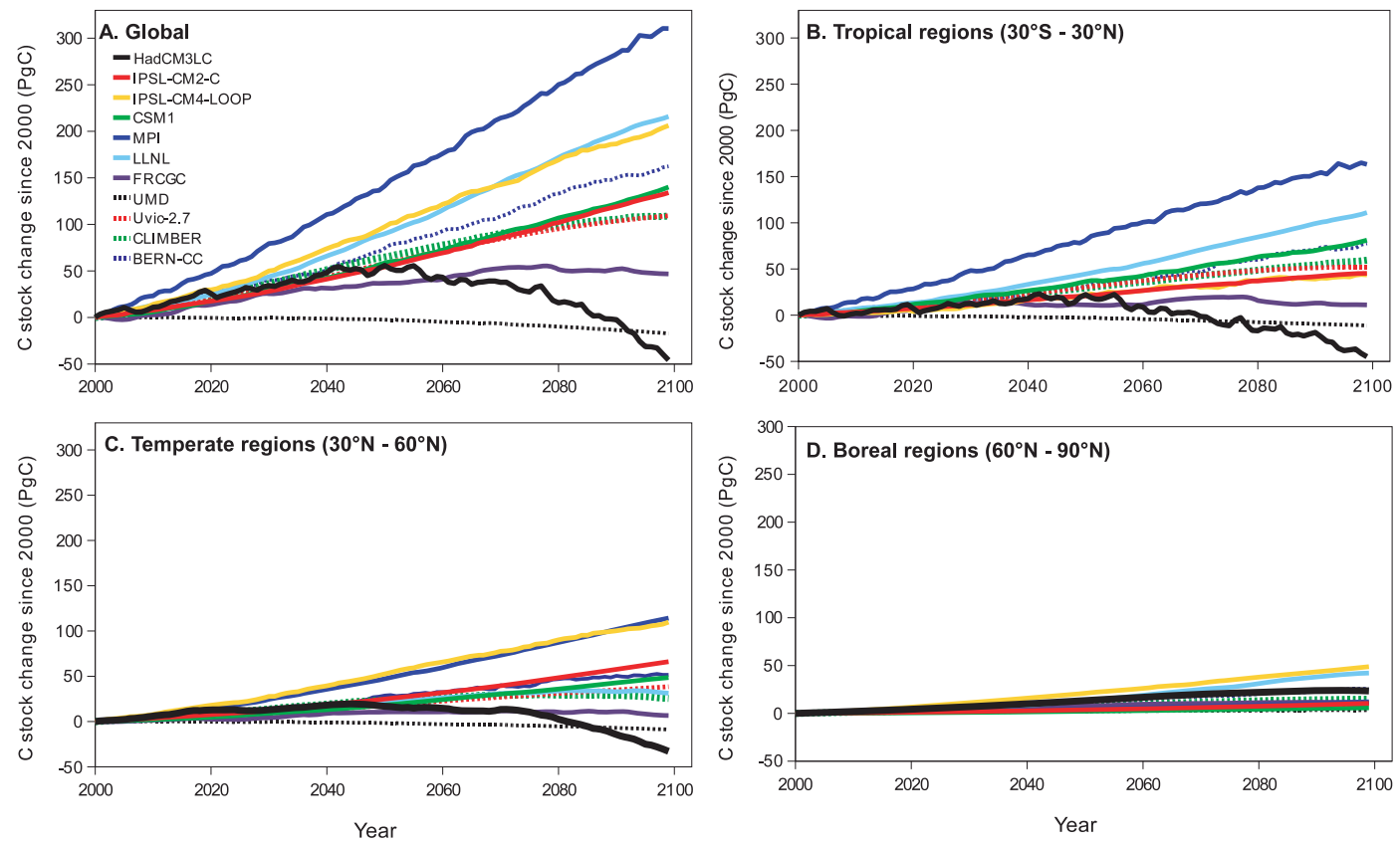

Fig. 6. Future evolution of global and regional soil organic carbon (SOC) stocks from 2000 to 2099 simulated by the 11 C4MIP model (Friedlingstein et al., 2006). 
common climate model. DGVMs are models that simulate changes in vegetation and in its associated biogeochemical and hydrological cycles in response to changes in climatic conditions. As for the C4MIP study, the SOC change in Sitch et al. (2008) over the 21 st century differs markedly between DGVMs. The range of model responses to climate change increases with intensive $\mathrm{CO}_{2}$ emission scenarios. Finally, the global SOC stocks change was predicted to range between a gain of $169 \mathrm{PgC}$ (Sheffield model with A1F1 scenario) and a loss of $58 \mathrm{PgC}$ (LPJ model with A1F1 scenario). Again, major differences between models are localized in the tropics. For the most extreme emissions scenario (A1F1), three of the five DGVMs (Hyland, LPJ, TRIFFID) simulate strong forest dieback and soil carbon loss in both the Amazon and African tropical forests, whereas there is a small increase of SOC stocks for ORCHIDEE and Sheffield (Sitch et al., 2008). Interestingly, even the boreal region remains controversial. Contrarily to the other models, LPJ simulates large reduction in the boreal forest coverage and large high-latitudes losses in soil carbon.

\subsection{Effect of future agricultural change}

Using the OSCAR global carbon model driven by land cover change in the IPCC A2 scenario (Gitz and Ciais, 2004), we estimated potential SOC changes between 2000 and 2099 in response to a land-use change scenario. The results split into four main regions are given in Table 2 and compared to ORCHIDEE-LUC simulations for the 20th century. In all regions except Africa and Latin America, warming-induced increases in NPP dominates over warming-induced increases in decomposition, resulting in a net SOC gain. Thus, it can be seen that land cover change in this particular scenario [SRES A2 with land use from the IMAGE2.0 model (Alcamo, 1994)] is glob- ally reducing the SOC increase due to climate change. In most regions and at global scale, climate-induced NPP increase dominates SOC loss due to land-use change. However, deforestation and warming-increased soil respiration drives the SOC balance to be strongly negative in Africa and Latin American regions, strongly limiting the future $\mathrm{C}$ sequestration in the global soil.

Over Europe, more detailed simulations of SOC have been analysed. Smith et al. (2005a,b) using the Roth C model reported that projected climate change to 2080 might have limited impact on cropland NBP due to the balancing effects of increased losses due to faster decomposition and increased inputs due to choice of crops/harvestable fraction and improved technology. They attributed uncertainties in future projections mainly to differences in projected climate (2000-2080) by four GCMs forced by the four IPCC SRES emission scenarios, and differing assumptions about the implementation of technology. Smith et al. (2005a,b) also suggested that croplands could become a net carbon sink under improved technology, but the uncertainty (due to climate projections and interactions between decomposition, NPP and technology) was also large, with a $9 \%$ uncertainty due to forecast changes in technology alone.

\subsection{Potential to increase SOC in agriculture}

Agricultural lands occupy about 40-50\% of the Earth's land surface. Agricultural practices can make a significant contribution at low cost to increasing soil carbon sinks (Smith et al., 2007; Smith, 2008).

Soil $\mathrm{C}$ sequestration can be achieved by increasing the net flux of $\mathrm{C}$ from the atmosphere to the terrestrial biosphere by increasing global $\mathrm{C}$ inputs to the soil (via increasing NPP), by storing a larger proportion of the $\mathrm{C}$ from NPP in the longer-term $\mathrm{C}$ pools in the soil, or by reducing $\mathrm{C}$ losses from the soils by

Table 2. Partitioning of global and regional SOC changes among land cover change and climate and $\mathrm{CO}_{2}$ effects using ORCHIDEE-LUC model from 1901 to 2000 and OSCAR model from 2000 to 2099

\begin{tabular}{|c|c|c|c|c|c|c|}
\hline \multirow[b]{2}{*}{ Regions } & \multicolumn{3}{|c|}{ ORCHIDEE-LUC (1901-2000) } & \multicolumn{3}{|c|}{ OSCAR (2000-2099) } \\
\hline & $\begin{array}{c}\text { Total } \\
\left(\mathrm{PgC} \mathrm{Mkm}^{-2}\right)\end{array}$ & $\begin{array}{c}\text { Climate }+\mathrm{CO}_{2} \\
\left(\mathrm{PgC} \mathrm{Mkm}{ }^{-2}\right)\end{array}$ & $\begin{array}{c}\text { Land cover } \\
\left(\mathrm{PgC} \mathrm{Mkm}^{-2}\right)\end{array}$ & $\begin{array}{c}\text { Total } \\
\left(\mathrm{PgC} \mathrm{Mkm}^{-2}\right)\end{array}$ & $\begin{array}{c}\text { Climate }+\mathrm{CO}_{2} \\
\left(\mathrm{PgC} \mathrm{Mkm}^{-2}\right)\end{array}$ & $\begin{array}{c}\text { Land cover } \\
\left(\mathrm{PgC} \mathrm{Mkm}^{-2}\right)\end{array}$ \\
\hline Global & -0.07 & 0.24 & -0.31 & 0.35 & 1.5 & -1.15 \\
\hline OECD & & & & 0.59 & 0.86 & -0.28 \\
\hline Canada & -0.29 & -0.01 & -0.28 & & & \\
\hline USA & -0.73 & 0.09 & -0.82 & & & \\
\hline Europe & -0.17 & 0.05 & -0.22 & & & \\
\hline Former Soviet Union & -0.2 & 0.32 & -0.52 & 3.85 & 3.73 & 0.12 \\
\hline Asia & & & & 1.75 & 3.36 & -1.61 \\
\hline Tropical Asia & 0.29 & 0.74 & -0.45 & & & \\
\hline China & 0.25 & 0.38 & -0.13 & & & \\
\hline Africa and Latin America & & & & -2.75 & -0.32 & -2.43 \\
\hline Africa & -0.15 & -0.08 & -0.06 & & & \\
\hline South America & 0.42 & 0.59 & -0.17 & & & \\
\hline
\end{tabular}


slowing decomposition. For soil $\mathrm{C}$ sinks, the best options are to increase $\mathrm{C}$ stocks in soils that have been depleted in $\mathrm{C}$, that is agricultural soils and degraded soils, or to halt the loss of $\mathrm{C}$ from cultivated peatlands (Smith et al., 2007). In this section we focus on the potential to increase SOC in agriculture.

About $90 \%$ of the total mitigation in agriculture arises from sink enhancement and about $10 \%$ arises from emission reduction (Smith et al., 2007). The most prominent mitigation options in agriculture are the restoration of cultivated organic soils, improved cropland management (including nutrient management, tillage/residue management and water management) and setaside/agro-forestry, improved grazing land management (including grazing intensity, increased productivity, nutrient management, fire management and species introduction, and restoration of degraded lands (using erosion control, organic amendments and nutrient amendments). The management practices needed to deliver this carbon sequestration in agriculture are described in detail in Smith et al. $(2007,2008)$.

Many reviews have been published recently discussing options available for soil $\mathrm{C}$ sequestration and mitigation potentials (see Smith, 2008 for a review). Most of the estimates for the sequestration potential of activities range from about 0.1 to $0.8 \mathrm{t}$ $\mathrm{C} \mathrm{ha}{ }^{-1} \mathrm{yr}^{-1}$, but some estimates are outside this range (Smith, 2008). When considering soil $C$ sequestration options, it is important also to consider other side effects, including the emission of other greenhouse gases. Smith et al. (2001) suggested that as much as one half of the climate mitigation potential of some $\mathrm{C}$ sequestration options could be lost when increased emissions of other greenhouse gases (nitrous oxide; $\mathrm{N}_{2} \mathrm{O}$ and methane; $\mathrm{CH}_{4}$ ) were included, and Robertson et al. (2000) has shown that some practices that are beneficial for SOC sequestration, may not be beneficial when all greenhouse gases are considered.

The most recent estimate (Smith et al., 2007; Smith, 2008) of the technical potential for SOC sequestration in agriculture globally is $\sim 1.3 \mathrm{PgC} \mathrm{yr}^{-1}$, but this is very unlikely to be realized. Economic potentials for SOC sequestration estimated by Smith et al. (2007) were $0.4,0.6$ and $0.7 \mathrm{PgC} \mathrm{yr}^{-1}$ at carbon prices of 0-20, 0-50 and 0-100 USD t $\mathrm{CO}_{2}$-equivalent ${ }^{-1}$, respectively. At reasonable $\mathrm{C}$ prices, then, global agricultural soil $\mathrm{C}$ sequestration seems to be limited to around $0.4-0.7 \mathrm{PgC} \mathrm{yr}^{-1}$. Even then, there are barriers (e.g. economic, institutional, educational, social) that impeded the economic potential to realize (Trines et al., 2006; Smith and Trines, 2007; Bellassen et al., 2010a). Because forest trees have a technical potential to sequester about $1-2 \mathrm{PgC}^{-1}$ (IPCC, 2000), the estimates for $\mathrm{C}$ sequestration potential in soils are of the same order. Similarly, the economic potential for $\mathrm{C}$ sequestration in forestry is similar to that for soil $\mathrm{C}$ sequestration in agriculture (IPCC, 2007).

\section{Uncertainties and future directions}

Many sources of uncertainties intervene in SOC change prediction in the context of atmospheric $\mathrm{CO}_{2}$ increase and climate change, and land use change. These uncertainties include both future evolution of incomplete understanding of several biogeochemical processes (SOC decomposition and stabilization and fire disturbances) and ecosystem management (forest and agriculture). These uncertainties are only partly illustrated by the spread in future SOC stocks changes as predicted by the current process-based models (see Section 5 and Fig. 6). Combination of results by Sitch et al. (2008) and table 2 gives a maximum range of $368 \mathrm{PgC}$ for SOC stocks changes during the 21 st century.

First of all, because of incomplete understanding of some important processes (noted below) some potentially important biogeochemical processes are not incorporated in global models. Among the most important are (i) the 'priming effect'; (ii) temperature sensitivity of the different SOC pools and (iii) the role of the mineralogy in SOC stabilization. First, several studies have shown that fresh organic matter input to soil can stimulate SOC mineralization (e.g. Fontaine et al., 2004, 2007). This process called 'priming effect' might provide a negative feedback in the carbon cycle-climate system or even it might induce a positive one (Heimann and Reichstein, 2008), if its long-term impact is proven. Indeed, if C inputs stimulate SOC mineralization, enhanced inputs due to increased NPP will also increase SOC mineralization. In this case, the soil $\mathrm{C}$ sink forecast by global models would be smaller than currently estimated. Secondly, the vulnerability of the different SOC pools to warming is highly debated. Some authors reported that labile compounds are more sensitive to warming (Liski et al., 1999), that recalcitrant compounds are more sensitive (Fierer et al., 2005) or that both compounds are equally sensitive (Fang et al., 2005). At the moment, global C models assume that all pools will respond uniformly to warming. That assumption remains to be demonstrated. Third, several studies observed that most SOC is stabilized through interaction with mineral surfaces (Mikutta et al., 2006; Basile-Doelsch et al., 2009) and that mineral types have a major impact on SOC storage and turnover (e.g. Feller and Beare, 1997; Torn et al., 1997). SOC turnover usually depends on clay content in soil C models. The clay content dependence of the turnover integrates the fact that the higher the surface area the higher the amount of organic molecules that can be adsorbed and protected from microbial enzymes. However, not only the surface area but also the reactivity of this surface will determine the protection of organic molecules (Kleber et al., 2007). Consequently, it may be necessary to take soil mineralogy explicitly into account in global soil C models. These three examples are not exhaustive and illustrate that further breakthrough in soil biogeochemical research may lead to major changes in the architecture itself of soil C models applied at global scales.

Moreover, the effects of agricultural practices on SOC turnover and stability are still poorly understood. For example, even the increased $\mathrm{C}$ sequestration under less intensive tillage practices is currently questioned (Baker et al., 2007). Besides the increasing adoption of reduced tillage practices worldwide, recent studies tend to show that the effect of no till adoption 
on $\mathrm{C}$ storage has been overestimated, because too shallow soil depths have been taken into account in most studies. It is now argued that conservation tillage does not accrue SOC stock but only redistribute within the soil profile (Baker et al., 2007; Anger and Eriksen-Hamel, 2005). However, the tillage of previously untilled soils induces a large and rapid loss of soil $\mathrm{C}$, which is poorly described by current models (Gottschalk et al., 2010) and the slower kinetics of $\mathrm{C}$ storage under adoption of untilled systems is even less taken into account. The controls exerted by soil structure on SOM mineralization and the feedbacks due to the role of SOM in stabilizing soil structure remain poorly conceptualized and described. Future evolution of cropland management is also a large source of uncertainties. Indeed, the changes in agricultural practices observed since the 1950s will continue and probably accelerate during the next century because of the development of new crop varieties (with improved productivity, smaller root/shoot ratios, etc.), environmental and agricultural policies, adaptation to climate change (irrigation), need for biofuel production, or other factors.

In forest, future management is also difficult to anticipate: on the one hand, more and more forest stands are either put into protection or certified under a sustainable forestry label, both of which limit the amount of wood that can be harvested. On the other hand, the rising demand for wood-energy and the increasing risk of catastrophic event (e.g. fire, pests, storms) with climate change will put an economic incentive to intensify management and shorten rotation length. Recent modelling studies are starting to assess the resulting outcome of these two trends. Pussinen et al. (2009), for example show that if felling is increased to meet the increase in wood demand, soil carbon in European forests will be reduced by about $10 \mathrm{tC} \mathrm{ha}^{-1}$ in 2100 compared to a 'current felling rate' scenario. In their model however, this decrease is offset by an increase in litterfall when the positive effect of climate change on tree growth is taken into account.

Finally, temporal changes in soil water deficit, windspeed, air temperature and humidity will modify the risk frequency and severity of forest fires or insect outbreaks and the consequent rapid loss of carbon from the biosphere (Kurz et al., 2008; Heimann and Reichstein, 2008). Using the Biome-BGC model, Bond-Lamberty et al. (2007) found that the C balance of the Canadian boreal forest was mainly driven by fire disturbances from 1948 and 2005. Thus, the increase in fire disturbances during this period resulted in carbon losses of $6.8 \pm 1.0 \mathrm{gC} \mathrm{m}^{-2}$ $\mathrm{yr}^{-1}$. But for soils, fire may be a global driver of long-term carbon storage because it converts a substantial proportion of plant biomass to black carbon, which remains in the soil for thousands of years (Wardle et al., 2008). Black carbon is therefore often proposed as an important long-term sink of soil carbon (Marris, 2006). Hence, the net effect of fire on soil C balance remains controversial. Less well documented are the impacts of insect outbreaks on the global carbon balance. Climate change will influence insect distribution and abundance (Kurz et al.,
2008). For example, it is predicted that outbreaks of mountain pine beetle in Canada will increase in both scale and severity due to the expansion of its habitat and may have an impact on annual $\mathrm{CO}_{2}$ emissions equivalent to forest fires through reduced NPP and increased heterotrophic respiration (Kurz et al., 2008). Insect outbreak may temporarily increase SOC stocks because of the large transfers of biomass to dead organic matter pools. But, as opposed to fire, no black carbon is produced.

\section{Conclusions}

SOC is the largest land biospheric carbon reservoir. Over the past century, climate and land cover change both have significantly changed the regional balance of SOC. Globally, according to simulations with the ORCHIDEE model covering the 20th Century, these two effects of opposite direction have nearly offset each other. In the simulation, tropical regions have gained carbon during the past century because ' $\mathrm{CO}_{2}$ - and rainfall-induced' NPP increase dominated 'warming increased' decomposition and SOC loss due to conversion of natural ecosystems into agricultural lands. Oppositely, boreal and temperate regions have lost carbon due to clearing of forests into arable lands in the early 20th century. Although mechanization of agriculture in the 1950s has accelerated SOC losses in croplands, development of carbon-sequestering practices over the past decades (no-till, irrigation, reduced use of bare fallows, land conservation program, increased crop residue incorporation, etc.) may have limited SOC losses in the recent years. Nowadays, croplands do not probably represent a strong source of $\mathrm{CO}_{2}$ to the atmosphere in Europe, China and USA. But regional, systematic inventories of the SOC balance of arable lands are basically lacking.

In the future, climate change may induce SOC release into the atmosphere if temperature and atmospheric $\mathrm{CO}_{2}$ concentration do not stabilize. According to the results of the terrestrial biosphere model ensembles of Friedlingstein et al. (2006) and Sitch et al. (2008), increased litterfall might not compensate anymore warming-increased decomposition in the future. Because future natural and human-induced land-use changes are not likely to induce large SOC storage, soils are expected to become a net source of $\mathrm{CO}_{2}$ to the atmosphere, accelerating the atmospheric $\mathrm{CO}_{2}$ increase and the subsequent warming. The timing and magnitude of projected SOC changes are considerably uncertain. Although most carbon-cycle models predicts that the net SOC balance will still remain positive for the 21 st century, several models simulates a fast SOC release during the last decades leading in some case to a negative SOC balance. The most vulnerable regions are consistently the tropical forests because of drought-induced forest dieback. But large high-latitudes $\mathrm{C}$ losses could also be expected because of permafrost thawing (not included in the model simulations presented in this review). A better incorporation into models of biogeochemical processes affecting SOC balance together with the identification of the 
most relevant future anthropogenic $\mathrm{CO}_{2}$ emissions and land-use scenarios are needed to reduce the uncertainties associated with the predictions of future SOC changes. Besides, the positive influence of some carbon-sequestering agricultural practices on SOC balance may encourage their use for climate change mitigation. More recent estimate of the technical potential for SOC sequestration in agriculture gives a potential global annual sink of $\sim 1.3 \mathrm{PgC} \mathrm{yr}^{-1}$, or a total SOC accumulation of $\sim 27 \mathrm{PgC}$ by 2030. However, this restoration of SOC is unlikely to be realized because of economic, institutional, educational and social barriers.

\section{Appendix: Brief description of the model tools used in this study}

\section{ORCHIDEE-LUC}

The ORCHIDEE model (Krinner et al., 2005) is a dynamic global vegetation model (DGVM) representing key vegetation processes governing terrestrial biogeochemistry and biogeography. In this study, however, we switched off vegetation dynamic simulation module because there are large uncertainties in DGVM modelled vegetation distribution (Krinner et al., 2005; Sitch et al., 2008). ORCHIDEE distinguishes 12 plant functional types with different photosynthetic, phenological and morphological characteristics. Heterotrophic respiration parameterization is taken from CENTURY (Parton et al., 1988). The current version of ORCHIDEE takes into account the effects of land use change on terrestrial $\mathrm{C}$ cycle as described in Piao et al. (2009a,b).

\section{ORCHIDEE-STICS}

ORCHIDEE-STICS is an evolution of the ORCHIDEE ecosystem model that is coupled to the STICS agronomy model describing crop phenology. More details of the model and applications can be found in de Noblet-Ducoudre et al. (2004), Gervois et al. (2004) and Gervois et al. (2008). ORCHIDEE-STICS was used to simulate changes in the European croplands $\mathrm{C}$ balance between 1901 and 2000. This simulation included winter wheat and maize, and ignored summer C3 crops (Gervois et al., 2008). The soil carbon decomposition module of ORCHIDEE-STICS is similar to the CENTURY model equations (Parton et al., 1988). Starting from ancestral farming practice and crop varieties in 1901, the model was driven over Western Europe by rising $\mathrm{CO}_{2}$ and reconstructed climate at a resolution of $10 \mathrm{~km}$, and by evolving agricultural technology. The technological evolution is reconstructed by Gervois et al. (2008), and includes the use of shorter growth cycle varieties, increased harvest index, increased $\mathrm{N}$-fertilizers and decreased manure applications, maize irrigation, and increased tillage which accelerates SOC decomposition.

\section{ORCHIDEE-FM}

ORCHIDEE-FM is an evolution of the ORCHIDEE ecosystem model. It includes a Forest Management Module that explicitly simulates forest stand growth and management (Bellassen et al., 2010b). This is made possible by the disaggregation of forest representation from an average tree to an average stand defined by a population of diameter classes. The model is able to calculate the critical stand self-thinning density above which natural mortality occurs due to competition. Based on the standard forestry principle of avoiding natural mortality, a set of rules are defined to calculate the recurrent intensity and frequency of thinning and forestry operations during the stand lifetime.

\section{OSCAR}

OSCAR is a global carbon cycle model including a reduced-form ocean model to quantify the ocean-atmosphere $\mathrm{CO} 2$ exchange and a terrestrial carbon cycle model to account for the fluxes between land and atmosphere (Gitz and Ciais, 2004). The parameterization of the biosphere was derived from the spatiallyexplicit CASA-SLAVE model (Friedlingstein et al., 2006). The terrestrial cycle integrates a detailed land-use module that allow for conversions of biomes, and calculates both the land-use related net $\mathrm{CO} 2$ emissions following anthropogenic disturbances as well as the terrestrial uptakes over the remaining undisturbed ecosystems at each time step. The global land cover is based on a simplified vegetation map, which is regionalized into four world regions as defined by the Intergovernmental Panel of Climate Change Third Assessment Report (IPCC, 2000) and shown in table 2: OECD-1990 (North America, Europe, Japan and Australia), Former Soviet Union, ASIA, ALM (Africa, Latin America and Middle East). In each region, six natural biomes are defined, plus three crop types (boreal, temperate, tropical) and cohorts of lands in transition between two biomes. Icy and hot desert were excluded. For each region, a biome has separate biophysical characteristics and it is assigned one surface area in the model.

\section{RothC}

RothC is a generic soil carbon model in non-waterlogged soils that allows for the effects of soil texture, temperature, moisture content and plant cover on the SOC turnover process (Jenkinson et al., 1987, 1991; Jenkinson, 1990). Soil carbon is split into four active compartments and a small amount of inert organic matter (IOM). The four active compartments are Decomposable Plant Material (DPM), Resistant Plant Material (RPM), Microbial Biomass (BIO) and Humified Organic Matter. Each compartment decomposes by a first-order process with its own characteristic rate. The IOM compartment is resistant to decomposition. Smith et al. (2005a,b) applied this model over Europe prescribed with input from changing NPP—discounted 
for harvest - from the LPJ vegetation model (Sitch et al., 2003). The RothC model was initialized and run at a resolution of $10 \mathrm{~km}$ from 1900 to 2100 and for four different IPCC future scenarios.

\section{LPJmL}

LPJmL where $\mathrm{mL}$ stands for managed lands is an evolution of LPJ (Sitch et al., 2003) that has been extended to represent the carbon and water cycles of managed land (Bondeau et al., 2007). The version cited in this study considers 11 crops functional types, eight of them being cultivated in Europe: temperate cereals (wheat like), maize, soybean, rice, temperate roots (sugarbeet like), sunflowers, rapeseed, pulses. The Leff et al. (2004) crop distribution is used to determine the grid cell fraction cover of each of these types within the cropland cover database provided for CarboEurope (Vetter et al., 2008) for the window $\left(15^{\circ} \mathrm{W}-60^{\circ} \mathrm{E} ; 30^{\circ} \mathrm{N}-75^{\circ} \mathrm{N}\right)$. The remaining crops are put within the temperate cereals type. For each type and each grid cell, the most appropriate crop variety is determined according to the climatic conditions. The sowing date, the heat unit requirements, and the base temperature, differ for each crop over the European window. For example, spring wheat is grown in higher latitudes, whereas winter wheat is grown over central and southern Europe.

\section{C4MIP}

In the context of the Coupled Climate-Carbon Cycle Model Intercomparison Project (C4MIP), seven coupled Ocean-Atmosphere General Circulation Models (OAGCMs) and four models of intermediate complexity performed coupled climate-carbon cycle simulations over the historical period and the 21 st century (Friedlingstein et al., 2006). All models used observed anthropogenic fossil fuel emissions for the historical period (Marland et al., 2005) and the Intergovernmental Panel on Climate Change (IPCC) Special Report on Emissions Scenarios (SRES) A2 emission scenario for the 2000-2100 period. Most models included land-use-associated CO2 emissions provided by Houghton and Hackler (2002) for the historical and by the Integrated Model to Assess the Global Environment (IMAGE)-integrated model for the 21 st century (Leemans et al., 1998). Land-use-associated emissions are seen here as an external forcing. More details on the models used in this study are presented in Friedlingstein et al. (2006).

\section{References}

Alcamo, J. 1994. IMAGE 2.0: Integrated Modelling of Global Climate Change. Kluwer Academic Publishers, Dordrecht.

Anger, D. A. and Eriksen-Hamel, N. S. 2005. Full inversion tillage and organic carbon distribution in soil profiles: a meta-analysis. Soil Sci. Soc. Am. J. 72, 1370-1374.

Angert, A., Biraud, S., Bonfils, C., Henning, C. C., Buermann, W. and co-authors. 2005. Drier summers cancel out the $\mathrm{CO}_{2}$ uptake enhance- ment induced by warmer springs. Proc. Natl. Acad. Sci. USA 102, 10823-10827.

Arrouays, D., Balesdent, J., Mariotti, A. and Girardin, C. 1995. Modelling organic-carbon turnover in cleared temperate forest soils converted to maize cropping by using C-13 natural abundance measurements. Plant Soil. 173, 191-196.

Baker, J. M., Ochsner, T. E., Venterea, R. T. and Griffis, T. J. 2007. Tillage and soil carbon sequestration - What do we really know? Agric. Ecosyst. Environ. 118, 1-5.

Baldocchi, D. 2008. Breathing of the terrestrial biosphere: lessons learned from a global network of carbon dioxide flux measurement systems. Austr. J. Botany 56, 1-26.

Balesdent, J., Wagner, G. H. and Mariotti, A. 1988. Soil organic matter in long-term field experiments as revealed by carbon-13 natural abundance. Soil Sci. Soc. Am. 52, 118-124.

Basile-Doelsch, I., Brun, T., Borschneck, D., Masion, A., Marol, C. and co-authors. 2009. Effect of landuse on organic matter stabilized in organomineral complexes: A study combining density fractionation, mineralogy and delta C-13. Geoderma 151, 77-86.

Beilman, D. W., MacDonald, G. M., Smith, L. C. and Reimer, P. J. 2009. Carbon accumulation in peatlands of West Siberia over the last 2000 years. Global Biogeochem. Cycles 23, GB1012, doi:10.1029/2007GB003112.

Bellamy, P. H., Loveland, P. J., Bradley, R. I., Lark, R. M. and Kirk, G. J. D. 2005. Carbon losses from all soils across England and Wales 1978-2003. Nature 437, 245-248.

Bellassen, V., Manlay, R. J., Chery, J. P., Gitz, V., Toure, A. and coauthors. 2010a. Multi-criteria spatialization of soil organic carbon sequestration potential from agricultural intensification in Senegal. Clim. Change 98, 213-243.

Bellassen, V., Le Maire, G., Dhote, J. F., Viovy, N. and Ciais, P. 2010b. Modeling forest management within a global vegetation model Part 1: Model structure, initial results, and sensitivity analysis. Ecol. Model. in press.

Bird, M., Chivas, A. R. and Head, J. 1996. Latitudinal gradient in carbon turnover times in forest soils. Nature 381, 143-145.

Bondeau, A., Smith, P. C., Zaehle, S., Schaphoff, S., Lucht, W. and co-authors. 2007. Modelling the role of agriculture for the 20th century global terrestrial carbon balance. Global Change Biol. 13, 679-706.

Bond-Lamberty, B., Peckhan, S. D., Ahl, D. E. and Gower, S. T. 2007. Fire as the dominant driver of central Canadian boreal forest carbon balance. Nature 450, 89-92.

Burke, I. C., Yonker, C. M., Parton, W. J., Cole, C. V., Flach, K. and co-authors. 1989. Texture, climate, and cultivation effects on soil organic-matter content in US grassland soils. Soil Sci. Soc. Am. J. 53, 800-805.

Canadell, J. G., Le Quere, C., Raupach, M. R., Field, C. B., Buitenhuis, E. T., and co-authors. 2007. Proc. Natl. Acad. Sci. USA 104, 18866-18870.

Cao, M. K., Prince, S. D. and Shugart, H. H. 2002. Increasing terrestrial carbon uptake from the 1980s to the 1990s with changes in climate and atmospheric $\mathrm{CO}_{2}$. Global Biogeochem. Cycles 16, 1069, doi:10.1029/2001GB001553.

Ciais, P., Schelhaas, M. J., Zaehle, S., Piao, S. L., Cescatti, A. and coauthors. 2008. Carbon accumulation in European forests. Nat. Geosci. 1, 425-429, doi:10.1038/ngeo233. 
Cox, P. M., Betts, R. A., Jones, C. D., Spall, S. A. and Totterdell, I. J. 2000. Acceleration of global warming due to carbon-cycle feedbacks in a coupled climate model. Nature 408, 184-187.

Davidson, E. A. and Janssens, I. A. 2006. Temperature sensitivity of soil carbon decomposition and feedbacks to climate change. Nature $\mathbf{4 4 0}$, $165-173$.

de Noblet-Ducoudre, N., Gervois, S., Ciais, P., Viovy, N., Brisson, N. and co-authors. 2004. Coupling the Soil-Vegetation-Atmosphere-Transfer Scheme ORCHIDEE to the agronomy model STICS to study the influence of croplands on the European carbon and water budgets. Agronomie 24, 397-407.

Fang, C. S. M., Smith, P., Moncrieff, J. B. and Smith, J. U. 2005. Similar response of labile and resistant soil organic matter pools to changes in temperature. Nature 433, 57-59.

Feller, C. and Beare, M. H. 1997. Physical control of soil organic matter dynamics in the tropics. Geoderma 79, 69-116.

Fierer, N., Craine, J. M., McLaughlan, K. and Schimel, J. P. 2005. Litter quality and the temperature sensitivity of decomposition. Ecology $\mathbf{8 6}$, 320-326.

Fontaine, S., Bardoux, G., Abbadie, L. and Mariotti, A. 2004. Carbon input to soil may decrease soil carbon content. Ecol. Lett. 7, 314-320.

Fontaine, S., Barot, S., Barré, P., Bdioui, N., Mary, B. and co-authors. 2007. Stability of organic carbon in deep soil layers controlled by fresh carbon supply. Nature 450, 277.

Friedlingstein, P., Cox, P., Betts, R., Bopp, L., von Bloh, W. and coauthors. 2006. Climate-carbon cycle feedback analysis: results from the C4mip model intercomparison. J. Clim. 19, 3337-3353.

Gervois, S., de Noblet-Ducoudre, N., Viovy, N., Ciais, P., Brisson, N. and co-authors. 2004. Including croplands in a global biosphere model: methodology and evaluation at specific sites. Earth Interact. 8, 1-25.

Gervois, S., Ciais, P., de Noblet-Ducoudre, N., Brisson, N., Vuichard, N. and co-authors. 2008. Carbon and water balance of European croplands throughout the 20th century. Global Biogeochem. Cycles 22, GB2022, doi:10.1029/2006GB002920.

Gitz, V. and Ciais, P. 2004. Future expansion of agriculture and pasture acts to amplify atmosphere $\mathrm{CO} 2$ levels in response to fossil-fuel and land-use change emissions. Clim. Change 67, 161-184.

Gottschalk, P., Bellarby, J., Chenu, C., Foereid, B., Smith, P. and coauthors. 2010. Simulation of soil organic carbon response at forest cultivation sequences using $13 \mathrm{C}$ measurements. Organic Geochem. 41, 41-54.

Heimann, M. and Reichstein, M. 2008. Terrestrial ecosystem carbon dynamics and climate feedbacks. Nature 451, 289-292.

Houghton, R. A. and Hackler, J. L. 2002. Carbon flux to the atmosphere from land-use changes. In: Trends: A Compendium of Data on Global Change, Carbon Dioxide Information Analysis Center, Oak Ridge National Laboratory, U.S. Department of Energy, Oak Ridge, TN.

Houghton, R. A. 2003. Revised estimates of the annual net flux of carbon to the atmosphere from changes in land use and land management 1850-2000. Tellus 55B, 378-390.

Houghton, R. A. 2007. Balancing the global carbon budget. Ann. Rev. Earth Planet. Sci. 35, 313-347.

Huang, Y. and Sun, W. 2006. Changes in topsoil organic carbon of croplands in mainland China over the last two decades. Chin. Sci. Bull. 51, 1785-1803.

IPCC. 2000. Special Report on Land Use, Land Use Change, and Forestry. Cambridge University Press, Cambridge, UK.
IPCC WGIII. (2007) Summary for policy makers. In: Working Group III Contribution to the Intergovernmental Panel on Climate Change Fourth Assessment Report. Climate Change 2007: Mitigation of Climate Change. Cambridge University Press, Cambridge.

Jain, A. K. and Yang, X. J. 2005. Modeling the effects of two different land cover change data sets on the carbon stocks of plants and soils in concert with $\mathrm{CO} 2$ and climate change. Global Biogeochem. Cycles 19, GB2015, doi:10.1029/2004GB002349.

Jenkinson, D. S., Hart, P. B. S., Rayner, J. H. and Parry, L. C. 1987. Modelling the turnover of organic matter in long-term experiments at Rothamsted. INTECOL Bull. 15, 1-8.

Jenkinson, D. S. 1990. The turnover of organic carbon and nitrogen in soil. Philos. Transact. R. Soc. 329, 361-368

Jenkinson, D. S., Adams, D. E. and Wild, A. 1991. Model estimates of $\mathrm{CO}_{2}$ emissions from soil in response to global warming. Nature 351, 304-306.

Jobbágy, E. G. and Jackson, R. B. 2000. The vertical distribution of soil organic carbon and its relation to climate and vegetation. Ecol. Appl. 10, 423-436.

Johnston, E., Poulton, P. R. and Coleman, K. 2009. Soil organic matter: its importance in sustainable agriculture and carbon dioxide fluxes. Adv. Agron. 101, 1-57.

Jolivet, C., Arrouays, D., Andreux, F. and Leveque, J. 1997. Soil organic carbon dynamics in cleared temperate forest spodosols converted to maize cropping. Plant Soil 191, 225-231.

Jones, C., McConnell, C., Coleman, K., Cox, P., Falloon, P. and coauthors. 2005. Global climate change and soil carbon stocks: predictions from two contrasting models for the turnover of organic carbon in soils. Global Change Biol. 11, 154-166.

Khvorostyanov, D. V., Krinner, G., Ciais, P., Heimann, M. and Zimov, S. A. 2008a. Vulnerability of permafrost carbon to global warming. Part I: Model description and role of heat generated by organic matter decomposition. Tellus Ser. B-Chem. Phys. Meteorol. 60, 250-264.

Khvorostyanov, D. V., Ciais, P., Krinner, G., Zimov, S. A., Corradi, C. and co-authors. 2008b. Vulnerability of permafrost carbon to global warming. Part II: Sensitivity of permafrost carbon stock to global warming. Tellus 60B, 265-275.

Kleber, M., Sollins, P. and Sutton, R. 2007. A conceptual model of organo-mineral interactions in soils: self-assembly of organic molecular fragments into zonal structures on mineral surfaces. Biogeochemistry 85, 9-24.

Koven, C., Friedlingstein P., Ciais, P., Khvorostiyanov, D., Krinner, G. and co-authors. 2009. The effects of cryoturbation and insulation by organic matter on the formation of high-latitude soil carbon stocks in a land surface model. Geophys. Res. Lett. 36, L21501, doi:10.1029/2009GL040150.

Krinner, G., Viovy, N., de Noblet-Ducoudre, N., Ogee, J., Polcher, J. and co-authors. 2005. A dynamic global vegetation model for studies of the coupled atmosphere-biosphere system. Global Biogeochem. Cycles 19, GB1015, doi:10.1029/2003GB002199.

Kuhlbusch, T. and Crutzen, P. 1995. Toward a global estimate of black carbon in residues of vegetation fires representing a sink of atmospheric $\mathrm{CO}_{2}$ and a source of $\mathrm{O}_{2}$. Global Biogeochem. Cycles 9, 491-501.

Kurz, W. A., Dymond, C. C., Stinson, G., Rampley, G. J., Neilson, E. T. and co-authors. 2008. Mountain pine beetle and forest carbon feedback to climate change. Nature 452, 987-990. 
Lal, R. 2003. Soil erosion and the global carbon budget. Environ. Int. 29, 437-450.

Lal, R. 2004. Carbon sequestration in soils of central Asia. Land Degrad. Develop. 15, 563-572.

Leemans, R., Kreileman, E., Zuidema, G., Alcamo, J., Berk, M. and co-authors. 1998. The IMAGE User Support System: Global Change Scenarios from IMAGE 2.1. RIVM Publication (CD-ROM) 4815006. National Institute of Public Health and the Environment (RIVM), Bilthoven, Netherlands.

Leff, B., Ramankutty, N. and Foley, J. 2004. Geographic distribution of major crops across the world. Global Biogeochem. Cycles $\mathbf{1 8}$, GB1009, doi:10.1029/2003GB002108.

Le Queré, C., Raupach, M. R., Canadell, J. G., Marland, G., Bopp, L. and co-authors. 2009. Trends in the sources and sinks of carbon dioxide. Nat. Geosci. 2, 831-836, doi:10.1038/ngeo689.

Lewis, S. L., Lopez-Gonzalez, G., Sonke, B., Affum-Baffoe, K., Baker, T. R. and co-authors. 2009. Increasing carbon storage in intact African tropical forests. Nature 460, 487-490.

Liski, J., Ilvesniemi, H., Makela, A. and Westman, C. J. 1999. CO2 emissions from soil in response to climatic warming are overestimatedthe decomposition of old soil organic matter is tolerant of temperature. Ambio 28, 171-174.

Lloyd, J. and Taylor, J. A. 1994. On the temperature-dependence of soil respiration. Funct. Ecol. 8, 315-323.

Magnani, F., Mencuccini, M., Borghetti, M., Berbigier, P., Berninger, F. and co-authors. 2007. The human footprint in the carbon cycle of temperate and boreal forests. Nature 447, 848-850.

Mäkelä-Kurtto, R. and Sippola, J. 2002. Monitoring of Finnish arable land: changes in soil quality between 1987 and 1998. Agric. Food Sci. Finland 11, 273-284.

Malhi, Y., Meir, P. and Brown, S. 2002. Forests, carbon and global climate. Philos. Transact. R. Soc. Lond. 360, 1567-1591.

Marland, G., Boden, T. A. and Andres, R. J. 2005. Global, regional, and national $\mathrm{CO}_{2}$ emissions. In: Trends: A Compendium of Data on Global Change (eds S. J. Marsland, H. Haak, J. H. Jungclaus, M. Latif and F. Roeske).Carbon Dioxide Information Analysis Center, Oak Ridge National Laboratory, U.S. Department of Energy, Oak Ridge.

Marris, E. 2006. Putting the carbon back: black is the new green. Nature 442, 624-626.

McGuire, A. D., Sitch, A., Clein, J. S., Dargaville, R., Esser, G. and co-authors. 2001. Carbon balance of the terrestrial biosphere in the twentieth century: analyses of $\mathrm{CO} 2$, climate and land use effects with four process-based ecosystem models. Global Biogeochem. Cycles 15, 183-206.

Mikutta, R., Kleber, M., Torn, M. S. and Jahn, R. 2006. Stabilization of soil organic matter: association with minerals or chemical recalcitrance? Biogeochemistry 77, 25-56.

Nabuurs, G. J., Thürig, E., Heidema, N., Armolaitis, K., Biber, P. and coauthors. 2008. Hotspots of the European forests carbon cycle. Forest Ecol. Manage. 256, 194-200.

Nemani, R. R., Keeling, C. D., Hashimoto, H., Jolly, W. M., Piper, S. C. and co-authors. 2003. Climate-Driven Increases in Global Terrestrial Net Primary Production from 1982 to 1999. Science 300, 1560-1563.

Ogle, S. M., Breidt, F. J., Eve, M. D. and Paustian, K. 2003. Uncertainty in estimating land use and management impacts on soil organic carbon storage for US agricultural lands between 1982 and 1997. Global Change Biol. 9, 1521-1542.
Parton, W. J., Stewart, J. W. B. and Cole, C. V. 1988. Dynamics of $\mathrm{C}, \mathrm{N}, \mathrm{P}$ and $\mathrm{S}$ in grassland soils - a model. Biogeochemistry $\mathbf{5}$, 109-131.

Parton, W. J., Myron, P. G., Williams, S. A., Easter, M. and Ojima, D. 2005. Ecological impact of historical land-use patterns in great plains: a methodological assessment. Ecol. Appl. 15, 1915-1928.

Paul, E. A., Paustian, K., Elliott, E. T. and Cole, C. V. 1997. Soil Organic Matter in Temperate Ecosystems. CRC Press, New York.

Paustian, K., Elliott, E. T. and Carter, M. R. 1998. Tillage and crop management on soil $\mathrm{C}$ storage: use of long-term experimental data. Soil and Tillage Research 47, 7-12

Paustian, K., Six, J., Elliott, E. T. and Hunt, H. W. 2000. Management options for reducing $\mathrm{CO}_{2}$ emissions from agricultural soils. Biogeochemistry 48, 147-163.

Petersen, B. M., Berntsen, J., Hansen, S. and Jensen, L. S. 2005. CN-SIM - a model for the turnover of soil organic matter I. Long-term carbon and radiocarbon development. Soil Biol. Biochem. 37, 359-374.

Peylin, P., Bousquet, P., Le Quere, C., Sitch, S., Friedlingstein, P. and co-authors. 2005. Multiple constraints on regional $\mathrm{CO}_{2}$ flux variations over land and oceans. Global Biogeochem. Cycles 19, GB1011, doi:10.1029/2003GB002214.

Piao, S. L., Fang, J. Y., Zhou, L. M., Zhu, B., Tan, K. and coauthors. 2005. Changes in vegetation net primary productivity from 1982 to 1999 in China. Global Biogeochem. Cycles 19, GB2027, doi:10.1029/2004GB002274.

Piao, S. L., Friedlingstein, P., Ciais, P., Zhou, L. M., Chen, A. P. 2006. Effect of climate and $\mathrm{CO}_{2}$ changes on the greening of the Northern Hemisphere over the past two decades. Geophys. Res. Lett., 33, L23402, doi:10.1029/2006GL028205.

Piao, S. L., Fang, J., Ciais, P., Peylin, P., Huang, H and co-authors. 2009a. The carbon balance of terrestrial ecosystems in China. Nature 458, 1009-1013.

Piao, S. L., Ciais, P., Friedlingstein, P., Noblet-Ducoudré, N., Cadule, P. and co-authors. 2009b. Spatio-temporal patterns of terrestrial carbon cycle during the 20th century. Global Biogeochemical Cycles 23, GB4026, doi:10.1029/2008GB003339.

Pregitzer, K. S. and Euskirchen, E. S. 2004. Carbon cycling and storage in world forests: biome patterns related to forest age. Global Change Biol. 10, 2052-2077.

Pongratz, J., Reick, C., Raddatz, T. and Claussen, M. 2008. A reconstruction of global agriculture areas and land cover for the last millennium. Global Biogeochem. Cycles 22, GB3018, doi:10.1029/2007GB003018.

Pongratz, J., Reick, C., Raddatz, T. and Claussen, M. 2009. Effects of anthropogenic land cover change on the carbon cycle of the last millennium. Global Biogeochem. Cycles 23, GB3488, doi:10.1029/2009GB003488.

Pussinen, A., Nabuurs, G. J., Wieggers, H. J. J., Reinds, G. J., Wamelink, G. W. W. and co-authors. 2009. Modelling long-term impacts of environmental change on mid- and high-latitude European forests and options for adaptive forest management. Forest Ecol. Manage. 258, 1806-1813.

Pypker, T. G. and Fredeen, A. L. 2002. Ecosystem $\mathrm{CO}_{2}$ flux over two growing seasons for a sub-Boreal clear-cut 5 and 6 years after harvest. Agricult. Forest Meteorol. 114, 15-30.

Qiu, J., Changseng, L., Wang, L., Tang, H., Li, H. and co-authors. 2009. Modelling impacts of carbon sequestration on net greenhouse 
gas emissions from agricultural soils in China. Global Biogeochem. Cycles 23, GB1007, doi:10.1029/2009GB001007.

Raich, J. W. and Schlesinger, W. H. 1992. The global carbon-dioxide flux in soil respiration and its relationship to vegetation and climate. Tellus Ser. B-Chem. Phys. Meteorol. 44, 81-99.

Reeves, M., Lal, R., Logan, T. and Sigaran, J. 1997. Soil nitrogen and carbon response to maize cropping system, nitrogen source, and tillage. Soil Sci. Soc. Am. J. 61, 1387-1392.

Reichstein, M., Subke, J. A., Angeli, A. C. and Tenhunen, J. D. 2005. Does the temperature sensitivity of decomposition of soil organic matter depend upon water content, soil horizon, or incubation time? Global Change Biol. 11, 1754-1767.

Reichstein, M. 2008. Impacts of climate change on forest soil carbon: principles, factors, models, uncertainties. In: Forestry and climate change (eds P. H. Freer-Smith, M. S. J. Broadmeadow and J. M. Linch). Wallingford, OECD, Forest Research, CABI Book, Wallingford, 127-135.

Robertson, G. P., Paul, E. A. and Harwood, R. R. 2000. Greenhouse gases in intensive agriculture: contributions of individual gases to the radiative forcing of the atmosphere. Science 289, 19221925.

Savage, K. E. and Davidson, E. A. 2001. Interannual variation of soil respiration in two New England forests. Global Biogeochem. Cycles 15, 337-350.

Schuur, E. A. G., Bockheim, J., Canadell, J. G., Euskirchen, E., Field, C. B. and co-authors. 2008. Vulnerability of Permafrost carbon to climate change: implications for the global carbon cycle. Bioscience 58, 701-714.

Shevliakova, E., Pacala, S. W., Malyshev, S., Hurtt, G. C., Milly, P. C. D. and co-authors. 2009. Carbon cycling under 300 years of landuse change: the importance of the secondary vegetation sink. Global Biogeochem. Cycles 23, GB2022, doi:10.1029/2009GB002022.

Sitch, S., Smith, B., Prentice, I.C., Arneth, A., Bondeau, A. and coauthors. 2003. Evaluation of ecosystem dynamics, plant geography and terrestrial carbon cycling in the LPJ dynamic global vegetation model. Global Change Biol. 9, 161-185.

Sitch, S., Huntingford, C., Gedney, N., Levy, P. E., Lomas, M. and co-authors. 2008. Evaluation of the terrestrial carbon cycle, future plant geography and climate-carbon cycle feedbacks using five Dynamic Global Vegetation Models (DGVMs). Global Change Biol. 14, 2015-2039.

Sleutel, S., De Neve, S. and Hofman, G. 2003. Estimates of carbon stock changes in Belgian cropland. Soil Use Manage. 19, 166-171.

Smith, P., Goulding, K. W., Smith, K. A., Powlson, D. S., Smith, J. U. and co-authors. 2001. Enhancing the carbon sink in European agricultural soils: Including trace gas fluxes in estimates of carbon mitigation potential. Nutr. Cycl. Agroecosyst. 60, 237-252.

Smith, P., Andren, O., Karlsson, T., Perala, P., Regina, K. and co-authors. 2005a. Carbon sequestration potential in European croplands has been overestimated. Global Change Biol. 11, 2153-2163.

Smith, J., Smith, P., Wattenbach, M., Zaehle, S., Hiederer, R. and coauthors. 2005b. Projected changes in mineral soil carbon of European croplands and grasslands, 1990-2080. Global Change Biol. 11, 2141-2152.

Smith, P., Martino, D., Cai, Z., Gwary, D., Janzen, H. H. and co-authors. 2007. Agriculture. Chapter 8 of Climate change 2007: Mitigation. Contribution of Working group III to the Fourth Assessment Re- port of the Intergovernmental Panel on Climate Change (eds B. Metz, O. R. Davidson, P. R. Bosch, R. Dave, L. A. Meyer). Cambridge University Press, Cambridge, United Kingdom and New York, NY, USA.

Smith, P. and Trines, E. 2007. Agricultural measures for mitigating climate change: will the barriers prevent any benefits to developing countries? Int. J. Agric. Sust. 4, 173-175.

Smith, P. 2008. Land use change and soil organic carbon dynamics. Nutr. Cycl. Agroecosyst. 81, 169-178.

Smith, P., Martino, D., Cai, Z., Gwary, D., Janzen, H. H. and co-authors. 2008. Greenhouse gas mitigation in agriculture. Philos. Transact. $R$. Soc., B. 363, 789-813.

Tarnocai, C., Canadell, J. G., Schuur, E. A. G., Kuhry, P., Mazhitova, G. and Zimov S. 2009. Soil organic carbon pools in the northern circumpolar permafrost region. Global Biogeochem. Cycles 23, GB2023, doi:10.1029/2009GB002023.

Torn, M. S., Trumbore, S. E., Chadwick, O. A., Vitousek, P. M. and Hendricks, D. M. 1997. Mineral control of soil organic carbon storage and turnover. Nature 389, 170-173.

Trines, E., Höhne, N., Jung, M., Skutsch, M., Petsonk, A. and coauthors. 2006. Integrating agriculture, forestry, and other land use in future climate regimes: methodological issues and policy options. Netherlands Environmental Assessment Agency, Climate Change - Scientific Assessment And Policy Analysis. Report 500102 002, 154.

Trumbore, S. 2000. Age of soil organic matter and soil respiration: radiocarbon constraints on belowground C dynamics. Ecol. Appl. 10, 399-411.

Trumbore, S. E., Davidson, E. A., Decamargo, P. B., Nepstad, D. C. and Martinelli, L. A. 1995. Belowground cycling of carbon in forests and pastures of Eastern Amazonia. Blobal Biogeochem. Cycles 9, $515-528$.

Valentini, R., Mateucci, G., Dolman, A. J., Schulze, E. D., Rebmann, C. and co-authors. 2000. Respiration as the main determinant of carbon balance in European forests. Nature 404, 861-865.

van Oost, K., Quine, T. A., Govers, G., De Gryze, S., Six, J., and coauthors. 2007. The impact of agricultural soil erosion on the global carbon cycle. Science 318, 626-629.

Vetter, M., Churkina, G., Jung, M., Reichstein, M., Zaehle, S. and coauthors. 2008. Analyzing the causes and spatial pattern of the European 2003 carbon flux anomaly in Europe using seven models. Biogeosciences 5, 561-583.

Walter, K. M., Smith, L. C. and Chapin, F. S. 2007. Methane bubbling from northern lakes: present and future contributions to the global methane budget. Philos. Trans. R. Soc. - Math. Phys. Eng. Sci. 365, 1657-1676.

Wardle, D. A., Nilsson, M.-C. and Zackrisson, O. 2008. Fire-derived charcoal causes loss of forest humus. Science 320, 629.

West, T. O. and Post, W. M. 2002. Soil organic carbon sequestration rates by tillages and crop rotation: A global data analysis. Soil Sci. Soc. Am. J. 66, 1930-1946.

Xie, Z. B., Zhu, J. G., Liu, G., Cadisch, G., Hasegawa, T. and co-authors. 2007. Soil organic carbon stocks in China and changes from 1980s to 2000s. Global Change Biol. 13, 1989-2007.

Yan, H., Cao, M., Liu, J. and Tao, B. 2007. Potential and sustainability for carbon sequestration with improved soil management in agricultural soils of China. Agric. Ecosyst. Environ. 121, 325-335. 
Zeng, N., Qian, H. F, Rödenbeck, C. and Heimann, M. 2005. Impact of 1998-2002 midlatitude drought and warming on terrestrial ecosystem and the global carbon cycle. Geophys. Res. Lett. 32, L22709, doi:10.1029/2005GL024607.

Zhao, M., Heinsch, F. A., Nemani, R. R. and Running, S. W.
2004. Improvements of the MODIS terrestrial gross and net primary production global data set. Remote Sens. Environ. 95, 164176.

Zimov, S. A., Schuur, E. A. G. and Chapin, F. S. 2006. Permafrost and the Global Carbon Budget. Science 312, 1612-1613. 